\title{
When Are Caregivers More Likely to Offer Sugary Drinks and Snacks to Infants?
}

Moore, Deborah; Goodwin, Tom; Brocklehurst, Paul; Armitage, Christopher; Glenny, Anne-Marie

\section{Qualitative Health Research}

DOI:

$10.1177 / 1049732316673341$

Published: 01/01/2017

Peer reviewed version

Cyswllt i'r cyhoeddiad / Link to publication

Dyfyniad o'r fersiwn a gyhoeddwyd / Citation for published version (APA):

Moore, D., Goodwin, T., Brocklehurst, P., Armitage, C., \& Glenny, A-M. (2017). When Are Caregivers More Likely to Offer Sugary Drinks and Snacks to Infants? A Qualitative Thematic Synthesis. Qualitative Health Research, 27(1), 74-88.

https://doi.org/10.1177/1049732316673341

\section{Hawliau Cyffredinol / General rights}

Copyright and moral rights for the publications made accessible in the public portal are retained by the authors and/or other copyright owners and it is a condition of accessing publications that users recognise and abide by the legal requirements associated with these rights.

- Users may download and print one copy of any publication from the public portal for the purpose of private study or research.

- You may not further distribute the material or use it for any profit-making activity or commercial gain

- You may freely distribute the URL identifying the publication in the public portal ?

Take down policy

If you believe that this document breaches copyright please contact us providing details, and we will remove access to the work immediately and investigate your claim. 


\section{Qualitative Health Research}

\section{When are caregivers more likely to offer sugary drinks and snacks to infants? A qualitative thematic synthesis}

\begin{tabular}{|r|l|}
\hline Journal: & Qualitative Health Research \\
\hline Manuscript ID & QHR-2016-0249.R4 \\
\hline Manuscript Type: & Research Article \\
\hline Keywords: & $\begin{array}{l}\text { Behavior Change }<\text { Behavior, Diet, Nutrition, Malnutrition, Parenting < } \\
\text { Families, Health Promotion < Health, Infants }\end{array}$ \\
\hline Regions, Cultures, and \\
Peoples: & $\begin{array}{l}\text { North America, North Americans, Western Europe < Europe, Europeans, } \\
\text { Australia, Australians }\end{array}$ \\
\hline Methods: & $\begin{array}{l}\text { Combined Methods < Research Design, Interpretive Methods < Research } \\
\text { Design, Meta Synthesis < Systematic Reviews < Research Strategies }\end{array}$ \\
\hline
\end{tabular}




\section{When are caregivers more likely to offer sugary drinks and snacks to infants?}

\section{A qualitative thematic synthesis}

*Deborah Anne Moore ${ }^{1,2}$, Tom Lloyd Goodwin ${ }^{1,2}$, Paul R Brocklehurst ${ }^{3}$, Christopher J

Armitage $^{4}$, Anne-Marie Glenny $^{1}$

${ }^{1}$ School of Dentistry, University of Manchester, United Kingdom

${ }^{2}$ Central Manchester University Hospitals NHS Foundation Trust

${ }^{3}$ NWORTH Clinical Trials Unit, University of Bangor, UK, United Kingdom

${ }^{4}$ School of Psychological Sciences, University of Manchester, United Kingdom

* Correspondence: Deborah.moore-2@manchester.ac.uk 


\section{Abstract}

Background: Many children consume more sugar than is recommended and caregivers often find it difficult to change this habit once established. This thematic synthesis aims to identify the 'critical situations' where caregivers may be more likely to offer infants sugary drinks and snacks.

Methods: This thematic synthesis is reported in accordance with the ENTREQ statement. Our confidence in the findings of our synthesis was assessed using the CERQual approach.

Findings: We included 16 studies, from the U.S, U.K, Australia and Denmark. We identified 8 'critical situations' when caregivers may be more likely to offer sugary drinks and snacks to infants.

Conclusions: Interventions that seek to reduce sugar intake for caries prevention in infants and young children may be more successful if they provide caregivers with practical parenting strategies to replace the non-nutritive functions of sugary foods and drinks, as opposed to taking an information-giving approach. 


\section{Introduction}

Over the last decade, global sugar consumption has grown from about 130 to 178 million tonnes (World Cancer Research Fund International, 2015). There is evidence of a log- linear relationship between free-sugar consumption and dental caries and recent data suggest that fluoride use in childhood may delay rather than eliminate the onset of caries when free-sugar consumption is greater than 3\% of energy intake (Sheiham \& James, 2014). In light of the evidence linking free-sugars consumption to both tooth decay and obesity (Morenga, Mallard, \& Mann, 2013; Moynihan \& Kelly, 2014), the World Health Organisation and the UK Scientific Advisory Commission for Nutrition (SACN) have recently recommend that they contribute no more than $5 \%$ of total energy intake (Scientific Advisory Committee on Nutrition, 2015; World Health Organisation, 2015). This proportion of free-sugars intake is equivalent to about 6 teaspoons for an adult, or 5 teaspoons for a 4-6 year-old child.

Many caregivers report that although they intend to limit intake of sugary drinks and snacks in their children, they struggle to do so, and this continues to be the case even after their child has experienced the pain and infection caused by extensive dental caries (Freeman, Ekins, \& Oliver, 2005; Herman, Malhotra, Wright, Fisher, \& Whitaker, 2012; Peerbhay, 2009). Research shows that food and drinks preferences are modified by repeat exposure during the early years and the flavours that an infant is exposed to have been shown to affect their food preferences in later life (Birch \& Marlin, 1982; Birch, 1998; Mennella \& Trabulsi, 2012; Ventura \& Mennella, 2011). Thus, for caries prevention in families identified as being at increased risk, it may be more effective to aim for the avoidance of creating a 'sugar habit' in infancy, rather than trying to restrict established sugar consumption in older children when they present to the dentist with tooth decay.

The aim of this qualitative thematic synthesis is to identify the "critical situations" when caregivers might be more likely to offer sugary drinks and snacks to infants aged 6-24 months, despite their intention to limit sugar intake. This age range is of particular interest because the foods and 
drinks that the infant consumes are entirely controlled by caregivers. Critical situations are cues, or 'triggers' to action, which may be internal or external. Internal triggers might relate to stress, happiness or fatigue, for example, whereas external factors might relate to geographical location, time of day, or the influence of people around us. Both internal and external factors may lead to habitual behavior (Gollwitzer \& Sheeran, 2006; Orbell, Hodgkins, \& Sheeran, 1997; Webb \& Sheeran, 2007), such as offering sugary drinks and snacks to infants, or older children. Identifying these critical situations is important because they can be harnessed to replace the unhelpful behavior with a prespecified, goal directed alternative (Gollwitzer, 1999). This would involve the caregiver making specific plans to employ an alternative strategy in a situation where their habitual response would be to offer their infant sugary drinks and snacks.

We begin, therefore, by reviewing the literature to determine the broad influences on the food and drinks choices that caregivers make for pre-school children up to the age of five. We then move to synthesise the results of our literature review, to produce our research findings - namely, a set of inferences about the 'critical situations' when caregivers may be more likely to offer sugary foods and snacks to infants.

\section{Methods}

This qualitative systematic review is presented in accordance with the ENTREQ statement for enhancing transparency in the synthesis of qualitative research (Tong, Flemming, McInnes, Oliver, \& Craig, 2012). A checklist showing where the review addresses each item of the ENTREQ statement is included in Supplemental File 1.

\section{Research questions}

1. What are the external and internal influences on caregivers of children aged 6 months -5 years living in high-income countries, in relation to what to give their child to eat and drink?

2. From the caregiver's perspective, what is the value of sugary drinks and snacks, and what are the negative consequences of not offering them to children aged 6 months to 5 years? 
3. When are the 'critical situations' where caregivers may be more likely to offer sugary drinks and snacks to infants aged 6-24 months?

Systematically reviewing and analyzing the qualitative literature on caregiver food choices for children aged 6months -5 years answered research questions 1 and 2 . Research question 3 is answered by the thematic synthesis, which constitutes the findings of our review. Our review findings are based on, but take an interpretative step beyond, the results of the literature review.

\section{Reflexivity statement}

The authors of this qualitative systematic review draw on a wide range of experience including dental public health, public health nutrition, political theory, health services research and health psychology. The authors are in agreement with recent recommendations to reduce sugar intake in young children, but are aware from clinical experience that many caregivers find it difficult to do so in practice. We began with the hypothesis that this may be due to the many non-nutritive roles that sugary drinks and snacks have in family life. The ontological and epistemological approach taken by the authors is critical realist (Maxwell, 2010). That is to say, we accept that a 'real world' does exist beyond our construction of it, but that its understanding, as presented here, is inevitably based on the perspectives and constructions of the participants and authors of the primary studies, as well as our own points of view.

\section{Inclusion and exclusion criteria}

Type of studies: Four reviewers (Deborah Moore, Tom Goodwin, Anne-Marie Glenny, Paul R. Brocklehurst) screened each study title and abstract in duplicate. Eligibility criteria were that the studies used qualitative methods of data collection and analysis and were conducted in a high-income setting in order to increase the transferability of the findings to our particular context, the U.K (The World Bank, 2014). Studies presenting questionnaire-based information only, studies not published in English or abstracts without citations were excluded.

Participants: We initially aimed to limit our search to studies where the children were infants, aged between 6 and 24 months. However, due to the small number of studies returned by preliminary 
searches, the inclusion criteria were extended to include caregivers of children up to 5 years of age.

This is reflected in research questions 1 and 2 relating to pre-schoolers. However, to answer research question 3, we narrowed our focus to identify the critical situations where caregivers may be more likely to offer sugary drinks and snacks to infants (6-24 months). Where a 'critical situation' was based only on knowledge gained from studies with caregivers of older children, this is reflected in the statement 'some concerns about relevance' in our 'CERQual assessment of confidence' for that finding (see below). We use caregiver here as an inclusive term to refer to parents, grandparents, or legal guardians of children who have responsibility for the wellbeing of a child.

Phenomena of interest: The internal and external cues experienced by caregivers when choosing foods and drinks, especially sugary drinks and snacks, for their pre-school child or infant. Studies concerned with the decision to breastfeed or not were excluded.

Full-text articles were obtained for any abstract which was identified by any single reviewer and which appeared to meet the above inclusion criteria. Final decisions at the full text stage were made by consensus agreement between four review authors (D. Moore, T. Goodwin, A. Glenny and P. Brocklehurst).

\section{Search Strategy}

The search strategy for this thematic synthesis is purposive rather than exhaustive. We originally planned to develop the search strategy in an iterative fashion. However, the initial search returned 16 studies, (reported in 17 papers) which provided a varied sample of ethnicities and socioeconomic status' populations from within our target context of high-income countries similar to the UK. We found that saturation of themes occurred after coding around 13 of the 16 studies. For these reasons it was decided to limit the search to the first iteration.

The electronic databases PsycINFO, Social Policy and Practice, ASSIA and Medline were systematically searched from the start of the database to October 2014. Searches used keywords and MeSH headings (in OVID). Filters designed by McMaster University to identify qualitative studies in Medline (92\% 
sensitivity, 92\% specificity) and PsycINFO (86\% sensitivity, 87\% specificity) were applied (Mc Master University, 2014a; McMaster University, 2014b). The full search history for each database is presented in Supplemental File 2.

\section{Quality assessment}

Deborah Moore and Tom Goodwin critically appraised the studies using a checklist that contained 11 domains, based on the CASP (CASP UK, 2013) and JBI (The Joanna Briggs Institute, 2014) tools. The final format was agreed after piloting both the CASP and JBI checklists. The domains included were: aims; research design; recruitment strategy; data collection; reflexivity; adequate representation of participants' voices; findings; relationship of conclusions to interpretation and analysis; congruity across study design, methods and analysis; ethical issues and value. Each review author carried out his or her critical appraisal separately, with the final decision reached after discussion. No studies were excluded on the basis of quality. Rather, studies were classified as low, moderate or high quality and were used as such to inform the CERQual assessment of confidence in the review findings (see below).

\section{Data extraction}

Two authors, (Moore and Goodwin) separately extracted data regarding study characteristics, methods and conclusions, using the standardized Data Extraction Template for Qualitative Evidence, produced by the Joanna Briggs Institute (JBI) (The Joanna Briggs Institute, 2014). Any discrepancies were addressed by agreement between the two reviewers. Following Thomas and Harden, 2008 (Thomas \& Harden, 2008), the data extracted for the thematic synthesis were the entire results sections of the primary papers, treating the text from the paper in the same way as a transcript from a primary source. At this stage, the review questions were put aside and the whole of the results sections were included as 'data'. Each reviewer individually annotated the paper manuscripts by hand and applied initial codes to describe discreet 'units of meaning' in the text. The two authors then met to discuss the codes and reach further agreement on meaning and terminology. One review author, Tom Goodwin, added the agreed codes to NVivo 10 software (QSR International) and extracted the 


\section{Qualitative Health Research}

appropriate sections of text for that code, directly from the electronic version of the manuscript.

Existing codes were then applied to each subsequent paper, where applicable, or new codes were created, if necessary, in a manner similar to the constant comparative method (Glaser \& Strauss, 1967; Urquhart, 2013). This process resulted in 52 initial codes, which were subsequently condensed into 33 non-hierarchical descriptive themes that represented a close summary of the content of the 17 papers.

\section{Synthesis}

Moore and Goodwin examined the 33 descriptive themes in light of the review's first two research questions, with a view to producing the 'analytical themes' given in the results section below (Thomas, J. \& Harden, A., 2008). Concepts in the 33 descriptive themes that could not inform these research questions were left behind at this stage. Examples of concepts that were not taken forward are: beliefs about physical activity; or mothers concerns about their own weight. The authors worked together to achieve consensus on the organisation of the analytical themes, as well as to ensure that the coded sections of text for each theme were internally consistent and that they adequately supported the phenomenon. The analytical thematic structure starts with the 'first-order' themes, which are essentially the descriptive themes found in the original papers. The second order themes represent areas of concern for caregivers. These areas of concern are then organised as third order themes, along a continuum of widening influence, from the parent-child dyad up to the influence of wider society.

Following the thematic synthesis approach (Thomas, J. \& Harden, A., 2008), Moore and Goodwin then proceeded to answer the third research question: "What are the 'critical situations' where caregivers may be more likely to offer sugary drinks and snacks to infants?" This more interpretive step involved, first, a consideration of how the analytical themes identified in the literature review could apply to food choice for infants in general, and second, what could therefore be inferred about the likely 'high-risk' scenarios where sugary drinks and snacks may be offered to them. This process necessitated some level of conceptual innovation due to the fact that we were 
asking a question that had not been considered in the primary studies. To facilitate this process, we drew upon our knowledge and experience from the fields of nutrition, public health, clinical dentistry, political theory and sociology. Christopher J. Armitage and Paul R. Brocklehurst then reviewed the proposed critical situations to ensure that they were plausible, that they were supported by the thematic synthesis and that they constituted appropriate definitions of a 'critical situation'.

The 'critical situations' are presented as review findings in table 2. To describe our confidence in the individual review findings, we used the Confidence in the Evidence from Reviews of Qualitative Research Approach (GRADE-CERQual) (Lewin et al., 2015). Following this approach our confidence in each review finding was weakened if we had concerns about the contributing body of evidence. Confidence was assessed by making a judgement across 4 domains: methodological limitations, relevance, coherence, and adequacy, outlined in detail below. Supplemental File 4, CERQual Judgment Table, gives the full reasoning behind each CERQual assessment of confidence in our findings.

- The methodological limitations refer to the extent to which there are problems in the design or conduct of the primary studies that contributed evidence to one of our review findings. This domain was assessed using the quality assessment described above. Where we had concerns about the design or conduct of the studies that contributed to a particular finding, our confidence in that finding was reduced.

- The relevance of the included studies to the review question refers to the extent to which the body of evidence from the primary studies supporting the review finding is applicable to the context of this review - i.e. caregivers of infants aged 6-24 months, living in a high-income, developed country setting. If a review finding was based entirely upon studies where the children of the caregivers were aged over 24 months, our confidence in that finding was reduced due to concerns about the 'relevance' of the evidence. However, if we felt that a specific finding would be equally applicable to caregivers of infants and older children, our confidence in the review finding was not particularly weakened. 
- The coherence of a review finding refers to the extent to which it is well grounded in data from the supporting primary studies and provides a convincing explanation for the patterns found in these data. Where variation was found across data from individual studies with no convincing explanation for this variation, we were less confident that the review finding is a coherent reflection of how caregivers choose food for infants.

- Adequacy of data refers to an overall determination of the degree of richness and the quantity of data supporting a review finding. Our confidence in a finding was weakened when it was supported by data from only one or few primary studies, settings or relevant groups, or the data supporting it were very thin.

Translating the analytical themes into critical situations and carrying out the CERQual assessment of confidence in our findings was carried out by Deborah Moore and Tom Goodwin.

\section{Results}

\section{General overview}

A total of 17 full-text articles were included, which reported 16 primary studies conducted in the USA ( 9 studies), UK (3 studies), Australia (3 studies) and Denmark (1 study). The systematic search flow diagram is presented in Supplementary File 3. A summary of the included studies and the results of our methodological quality assessment are provided in Supplemental File 4, Summary Table of Included Studies.

The themes related to caregiver food choices for pre-schoolers are summarised in Table 1 and are described in the narrative of the results section. The final result of our thematic synthesis; the 'critical situations', where caregivers may be more likely to offer sugary drinks and snacks to infants, are presented in table 2 as our review 'findings'. Our confidence in the evidence that underpins each finding is described by the CERQual assessment, also in Table 2.

[INSERT TABLE 1 AND TABLE 2 HERE] 


\section{Child focused factors}

\section{Behavior management}

In many studies, caregivers reported using foods such as chocolate, sugary drinks and sweets, or fast foods to manage their child's behavior. This included using these foods to reward good behavior (Carnell, Cooke, Cheng, Robbins, \& Wardle, 2011; Hughes, Sherman, \& Whitaker, 2010; Lindsay, Sussner, Greaney, \& Peterson, 2010) to "treat" children (Carnell et al., 2011) "motivate" (Lindsay, Sussner, Greaney, \& Peterson, 2009) or make them feel "special” (Tipton, 2014). 'I felt it was hard on S. to be dragged round on my errands, and that a couple of small sweets after a good breakfast wouldn't hurt."' (Carnell et al., 2011)

"Treat" foods were also used to manage a child's behavior using bribery, or as a reward for eating other healthier foods (A Horodynski \& Arndt, 2005; Hughes et al., 2010; Lindsay et al., 2010; Moore, Tapper, \& Murphy, 2010); “'If you quit crying, you know, you might get that candy bar after supper. But if you keep crying after I've already told you, then you won't."' (Hughes et al., 2010). “... mothers reported promising their children sweets and ice cream to reward a good behavior or to get them to do something. In some cases, mothers also reported using "bad foods" to get their children to eat “good foods." (Lindsay et al., 2010)

Caregivers also used foods to distract children or to keep them quiet (Carnell et al., 2011; Omar, Coleman, \& Hoerr, 2010; Tipton, 2014); '"They'll [sugar sweetened beverages] kind of keep him, you know, pre-occupied"' (Tipton, 2014). "'The treat is a chocolate bar and a packet of crisps just for something more interesting to keep her occupied while I shopped I suppose" (Carnell et al., 2011).

\section{Socialisation of the child}

Families in many of the studies seemed to operate according to their own rules, rituals and routines, as such creating a distinct 'food culture' within the home. The food culture relates to what foods are seen as acceptable, at what times (Carnell et al., 2011; Herman et al., 2012; Moore et al., 2010; Nielsen, Michaelsen, \& Holm, 2013). Caregivers emphasised the importance of teaching their child a "'normal or acceptable way of eating"' (Carnell et al., 2011), for example; '“She can be very 


\section{Qualitative Health Research}

greedy with sweets and chocolate and crisps. She can have one a day - like yesterday morning she said 'can I have a packet of crisps, it's 11 o'clock in the morning.'” (Moore et al., 2010)

The importance for caregivers of being responsive to their child's preferences and encouraging their child's growing autonomy was a common theme (Carnell et al., 2011; Duncanson \& Burrows, 2013; Herman et al., 2012; Horodynski, Brophy-Herb, Henry, Smith, \& Weatherspoon, 2009; Lindsay et al., 2010);

"Mothers repeatedly indicated that children were unique with regard to their food preferences how much of each type of food they would usually eat on any given day. Mothers appeared to honor and value this expression of their child's individuality and wanted to be responsive to it." (Herman et al., 2012).

Caregivers also reported using food to teach life lessons, such as the notion of not always getting what you want; "Sometimes they get mad and fall out but, that's something you have to deal with. We don't always get what we want. That's life."' (Herman et al., 2012).

Conversely, exposure to unhealthy snack foods was seen as beneficial by caregivers in some studies, deemed necessary in order to teach control and self-discipline; " I think the kids now and then need to eat a little bit of rubbish . . . that little bit for balance so they know when to control themselves."' (Pagnini, Wilkenfeld, King, Booth, \& Booth, 2007). "'Teaching the child some rules of conduct about the intake of confectionery, fizzy drinks and cake was therefore an important concern of mothers."' (Nielsen et al., 2013).

The notion of food for pleasure or enjoyment emerged as a theme in just two of the studies. In one sense this was connected to the idea of teaching children to try and enjoy a variety of foods (Carnell et al., 2011) but in another sense it was merely about giving children food that was “"palatable and pleasing"' (Kalinowski et al., 2012).

Despite the importance attached to the notion of restraint, caregivers in some studies mentioned special occasions, such as celebrations, or weekends as exceptions where children should be allowed to consume less healthy foods (Carnell et al., 2011; Duncanson \& Burrows, 2013); “'It's not worth fighting it is it, [Christmas is] one time of the year and that's it!'” (Carnell et al., 2011) 


\section{Promotion of child health}

One of the most common factors reported to affect caregiver food choices was the recognition that providing a balanced and varied diet was very important (A Horodynski \& Arndt, 2005; Carnell et al., 2011; Duncanson \& Burrows, 2013; Moore et al., 2010; Nielsen et al., 2013); “"My responsibility is to expose them to foods from all of the food groups and make sure that they're all in good balance."'

(Duncanson \& Burrows, 2013).

Limiting sugar intake to prevent cavities or hyperactivity was reported to be a common goal (Carnell et al., 2011; Herman et al., 2012; Tipton, 2014); “'He wouldn't be able to have sweets or a cake or biscuit, because I don't like him to have too many sweet things really. Because of his teeth I suppose."' (Carnell et al., 2011) 'She knows I don't want my kids eating candy, because I don't want their teeth all messed up"' (Herman et al., 2012).

Whilst these broad principles were seen as 'common sense', in some studies the authors noted that caregivers had a tendency to overestimate their nutrition knowledge or were unable to recall specific nutritional guidelines (A Horodynski \& Arndt, 2005; Duncanson \& Burrows, 2013; Hildebrand \& Shriver, 2010; Omar et al., 2010); “I can recall, I mean two, one to two pieces of fruit a day, I think it's three to four serves of vegetables a day; I couldn't tell you the amount of meat, I honestly don't know.'” (Duncanson \& Burrows, 2013).

One study reported that nutrition messages were seen by some caregivers as less important than fitting in with the general dietary patterns of the rest of the family; "Still, some limits to such adjustments of the family food pattern were reported. Although the liver and heart were believed to be healthy, many mothers refused to make this part of the family meal repertoire...'' (Nielsen et al., 2013).

Caregivers in some studies reported that their feeding choices were influenced by their perception of both the child's health, as well as the health history of their immediate family. There was evidence that caregivers tended to be more restrictive if there was a family history of obesity or chronic disease (Carnell et al., 2011; Duncanson \& Burrows, 2013; Lindsay et al., 2010); “'Because we've got, our family, my dad, my brother, they're all very big people and they are bigger because they eat lots of sometimes food. So I think that's why I'm so stern on what I teach my kids too because yeah, it's 
hereditary"' (Duncanson \& Burrows, 2013).

Conversely, caregivers in a range of studies reported being more permissive if they perceived their child to be fussy, underweight or unwell (Carnell et al., 2011; Omar et al., 2010; Pagnini et al., 2007); “"My younger boy he was underweight, he has sickle cell disease so he was underweight so I get very worried if he doesn't eat as well and any time he eats I'm very happy, I let him eat anything he wants."' (Carnell et al., 2011).

\title{
Everyday lives of caregivers
}

\section{Desire for family harmony}

The desire to preserve family harmony, by avoiding conflict, and disruption to routines and schedules emerged as influencing the food choices that caregivers make for their children. In a number of studies, caregivers mentioned that they would ignore their own feeding goals or nutritional advice to avoid conflict or disturbance to other members of the family (A Horodynski \& Arndt, 2005; Carnell et al., 2011; Freeman \& Stevens, 2008; Hughes et al., 2010; Nielsen et al., 2013; Tipton, 2014). In two studies, caregivers seemed particularly concerned with limiting disruptions during the night (Freeman \& Stevens, 2008; Nielsen et al., 2013). This was cited in one study as a reason to put a bottle in the child's bed at night, against advice from health professionals.

\author{
'"My Jimmy, he couldn't stand the child squealing and crying at night. We hadn't slept for weeks \\ and Jimmy and me were fighting like and Jimmy's shouting at me like; 'For flip sake give that child \\ a bottle, I can't be doing without sleep'. So I did, the child sleeps, no longer screams the house \\ down at night.'” (Freeman \& Stevens, 2008)
}

In order to avoid conflict and to promote family harmony, a number of caregivers mentioned that they would let children consume "whatever they liked" (Carnell et al., 2011; Nielsen et al., 2013). In many cases, this resulted in unhealthy choices (A Horodynski \& Arndt, 2005; Freeman \& Stevens, 2008; Tipton, 2014); "We'll just give it [fast food] to her if she's throwing a fit"” (A Horodynski \& Arndt, 
2005). “'Offering [sugar sweetened beverages] to calm children who are "acting out" arose as a common practice."' (Tipton, 2014).

Food refusal was cited as a common disruption in a number of studies (Duncanson \& Burrows, 2013; Horodynski et al., 2009; Moore et al., 2010; Tipton, 2014). In order to promote family harmony and avoid conflict caregivers may be more likely to offer infants the foods and drinks that they know they will eat. Many caregivers believe that children intrinsically dislike vegetables, and this was seen as a limitation on food choices for young children, and caregivers sometimes unwittingly reinforced this idea; "So we say, have it with a bit of meat or something like that to try to mask that horrible flavour of the particular vegetable”' (Duncanson \& Burrows, 2013).

In contrast to the common belief that children dislike vegetables, caregivers in one study expressed the belief that “...the sweet taste of SSBs made them easier to serve to preschoolers than more healthful beverages". (Tipton, 2014)

Caregivers were very concerned that their child should not be hungry, and this meant that they sometimes found it hard to say no to requests for snack foods or encouraged their child to eat more than they wanted to (Carnell et al., 2011; Hughes et al., 2010; Moore et al., 2010; Nielsen et al., 2013; Omar et al., 2010); “'I think it is hard to say no because you don't know if they're hungry or not. 'Cause you're not in their belly."' (Hughes et al., 2010).

Caregivers' strong desire to avoid a hungry child meant that they sometimes resorted to offering sugary snack foods, because they know that their child will eat them (A Horodynski \& Arndt, 2005; Carnell et al., 2011; Omar et al., 2010); “'...He's always going to eat a Snickers or a candy bar or something... I'll let him eat that without arguing about eating the junk food [a] lot of times just as long as I know he's filling up on something'”' (Omar et al., 2010).

In a number of studies, caregivers indicated that this concern to avoid a hungry child was in part driven by a desire to minimize the potential disruption to family harmony caused by a hungry child. This was seen as especially important to avoid between planned mealtimes and again, throughout the night; "You want her to be very full at night, so that I can sleep as much as possible." 
(Nielsen et al., 2013). "'I offered...more pasta as I didn't want her to say she was hungry later at bedtime."' (Carnell et al., 2011).

There were varying levels of resolve to limit unhealthy foods and drinks reported by caregivers, both within and between studies. A minority of participants in some studies reported a strong resolve to say 'no' to their children's demands for foods and drinks in the face of disruptive behavior (Carnell et al. 2011; Herman et al. 2012; Nielsen et al. 2013; Peters et al. 2014). "'I'll say if he can or he can't"' mentioned one parent (Carnell et al., 2011); “'whatever you do it's still a no"' stated another (Peters et al., 2014). '“Yeah, they have to ask me first and if I say 'no,' that means no, point blank. I don't care if you're mad at me, I don't care if you cry. You can't have it...'” (Herman et al., 2012). Whereas some caregivers found saying "no" much more difficult; "I give in sometimes. I give in to her because she looks like me. Her eyes are big and she just bats her eyes and she's like, "Ma, please?" And then I'm like, “Okay".'”' (Herman et al., 2012)

Of the four studies where caregivers reported a strong resolve, three were from samples of moderate or higher socio-economic status (Carnell et al., 2011; Nielsen et al., 2013; Peters et al., 2014). In the most contrasting study, where choices regarding child feeding was being led almost entirely by a desire to preserve family harmony (Freeman \& Stevens, 2008), the sample contained families who were coping with high background levels of conflict and disharmony - described by the authors as "chaotic lives"; "I can't stick the screaming at night. The only way to get him over (to sleep) is to give him a bottle of milk.'”(Freeman \& Stevens, 2008). We hypothesise that a high degree of existing family disharmony may limit caregivers' resolve to adhere to their own feeding goals.

\section{Competing demands}

The competing demands that caregivers face in their everyday lives appears to influence the food choices they make for their infants. Caregivers in some studies discussed how the need to keep to family schedules (Carnell et al., 2011; Nielsen et al., 2013), work commitments both inside (Lindsay et 
al., 2009; Nielsen et al., 2013) or outside of the home (Freeman \& Stevens, 2008; Lindsay et al., 2009; Nielsen et al., 2013; Omar et al., 2010), the provision of care and "treatment for special-needs children" (Omar et al., 2010), or "busy lives" in general (Peters et al., 2014) all created time pressures which affected food choices for their children.

'II don't cook and I'm the only one who can cook...but I'm never there. There will be nights I'll work 18 hours straight and I'll be up at 6:00 in the morning and go to work, not get home until 10, 11, 12 at night, and got to be up at 6:00 the next morning... When I do feed her, it's McDonald's, Burger King, something like that [that] I can grab and go...because I don't have the time."' (Omar et al., 2010)

Some caregivers stated that they found it harder to be consistent in how they fed their child if they were "tired" or "rushed" (Duncanson \& Burrows, 2013; Hughes et al., 2010), where others reported that they were more likely to eat out at restaurants when they did not "feel like cooking" (Lindsay et al., 2009). The convenient packaging of sugar sweetened beverages was a consideration for some caregivers and cited as a positive attribute of sugary drinks (Tipton, 2014).

Caregivers in a few studies mentioned that their own need for peace and quiet sometimes affected the food choices they made for their young children (Freeman \& Stevens, 2008; Hughes et al., 2010; Omar et al., 2010); “"My patience had done run out and I gave him the cake ... so I could sit down and relax."' (Hughes et al., 2010).

Caregivers reported that they found it harder to set limits and were more likely to "give in" to children's demands when they had higher background stress levels due to "strain and fatigue from work" (Hughes et al., 2010). "'Sugary drinks they, I guess it'll keep a kid calm cause sometimes...cause if a parent comes home from work, they don't feel like hearing no whining and crying and-alright, here."' (Tipton, 2014)

In most of the studies caregivers used highly emotive language to describe their experiences of feeding young children. They spoke of feeling "frustrated", "exasperated" and "anxious" (Duncanson \& Burrows, 2013; Herman et al., 2012) as well as experiencing "joy" "pride", "gratification" and "delight" 
(Duncanson \& Burrows, 2013; Freeman \& Stevens, 2008; Kalinowski et al., 2012; Moore et al., 2010), depending on their child's response to the foods and drinks they offered; "I don't know (long, silent pause). You just don't know, you just try anything. You try and get anything down their throat... I'd say he's made me ill."' (Moore et al., 2010).

Some described feeling "guilty" or "hurt" when denying children sweets or snack foods; '"Sometimes it hurts you as a parent more than the child when you say no. I don't know why though. I don't like my son looking all upset or crying...”' (Herman et al., 2012). In some cases, caregivers fed their child in a way that ameliorated their own difficult emotions; "If you don't have time, then you start to feel guilty and then you go and buy for the kids that new cereal with sugar...'” (Lindsay et al., 2009). “'Setting limits ... it's hard. . I think parents feel guilty. I think it's a big part of it....you don't see them until six, seven o'clock at night. It's hard to say no. You feel sorry.'” (Hughes et al., 2010)

\section{Wider society}

\section{Social networks}

Food choices for infants appear to be influenced by the social networks around the family and by the memories caregivers have of their own feeding experiences as children. Caregivers in some studies talked about how they tried to improve upon their own childhood experiences (Herman et al., 2012; Kalinowski et al., 2012; Moore et al., 2010), which generally had the effect of them being more permissive than their own parents; “I just want my children to have the things that I didn't have. I didn't have the choice to ask or, you know, I mean I can't speak for everyone in this room but my childhood wasn't very good growing up. So I just try to give them the highlights and things that I didn't have."' (Herman et al., 2012)

In one study of recent South American immigrants to the US, there was a cultural perception that having a "chubby" or "cute fat" infant was desirable and that if a child was thin it was a sign of bad parenting (Lindsay et al., 2010); “'In the Latino culture we have the tendency to think that the kids are healthy when they are fat"' (Lindsay et al., 2010) 
Grandparents and other family members were often discussed as a negative influence due to their tendency to indulge children with sweets and treat foods (Duncanson \& Burrows, 2013; Herman et al., 2012; Hughes et al., 2010; Lindsay et al., 2010; Omar et al., 2010; Pagnini et al., 2007; Peters et al., 2012; Tipton, 2014); “'Children say grandma is better. Grandmother feeds them candy and soda... they know they can have soda at grandma's house."' (Lindsay et al., 2009). In some cases grandparents were reported as seeing food as an expression of love (Herman et al., 2012; Pagnini et al., 2007).

\begin{abstract}
'"The worst ever is with my mom's mom, because my mom does it [feed the child sweets] but my grand mom feels like she did it with me so she's going to do it with my son. And she's at that whole stage where she's like, 'I'm not going to be here that much longer so I want them to love me and be happy with me'”. (Herman et al., 2012)
\end{abstract}

Mothers often reported being undermined by their own parents, grandparents or parents-inlaws when attempting to restrict sweets and snacks (Herman et al., 2012; Hughes et al., 2010; Lindsay et al., 2010; Pagnini et al., 2007; Tipton, 2014). As grandparents often provide free childcare, parents may find it especially difficult to disagree with them over food choices for their infants (Duncanson \& Burrows, 2013).

However, in some cases the influence of grandparents was discussed as a positive influence (Duncanson \& Burrows, 2013; Pagnini et al., 2007) and in one study fathers reported that they would be more likely to trust their parental advice on child feeding than that of a professional, even if it was contradictory; "II always stick to what my in-laws and parents say about that. I would never bring in nobody else, because I've been with them a lot and I'd rather be with somebody I know instead of somebody else telling me."' (Omar et al., 2010).

Some caregivers found that their children's requests for food were influenced by what their children's friends or other siblings were eating (Carnell et al., 2011; Duncanson \& Burrows, 2013; Horodynski et al., 2009); “I don't want to make him unhappy saying he can't have things and other children can, I don't think it would be very nice."' (Carnell et al., 2011) 


\section{Qualitative Health Research}

In one study caregivers mentioned that they felt social pressure to give their children treats, which included food; “'We feel like we've got to give our kids things all the time, they have got to have the best toys, they've got to have this because they want it, we have got to take them to McDonald's ... '“ (Pagnini et al., 2007). "For some, treats were almost seen as entitlements, and not providing them was referred to as a form of deprivation" (Pagnini et al., 2007)

\section{Food environment}

Availability and access to foods appear to be a significant influence on food choices for infants. Cost was cited as a common consideration (Carnell et al., 2011; Hildebrand \& Shriver, 2010; Horodynski et al., 2009; Lindsay et al., 2009; Omar et al., 2010; Pagnini et al., 2007; Peters et al., 2012; Tipton, 2014). For some families, this meant the substitution of certain items for cheaper versions; “'I'll say "No you're not having that, it's 60p for a yoghurt, choose something else."' (Carnell et al., 2011). Whereas in other studies, where incomes were more limited, cost was specifically cited as a reason for not buying fruit (Hildebrand \& Shriver, 2010; Horodynski et al., 2009; Lindsay et al., 2009; Omar et al., 2010); “'Sometimes, not always, but some months, you have to restrain yourself to just food, nothing else but food and you can't buy such and such cereal or a lot of fruit because fruits are expensive."' (Lindsay et al., 2009). "“The only thing that keeps me from buying them [fruit] would be expense."' (Hildebrand \& Shriver, 2010). In contrast, one reason that caregivers gave for choosing sweetened soft drinks were that they were less costly than other, more healthy drinks (Tipton, 2014).

Caregivers in some studies discussed the negative impact of television advertising, product placement and supermarket and fast food chain promotions on children's food preferences, though this may be more applicable to caregivers of older children, rather than infants (Duncanson \& Burrows, 2013; Lindsay et al., 2009; Pagnini et al., 2007; Peters et al., 2012; Tipton, 2014).

Caregivers felt that day care had an important place in promoting healthy eating and they all expected that their child would receive nutritious food at nursery and day care centres (Duncanson \& 
Burrows, 2013; Nielsen et al., 2013; Pagnini et al., 2007; Peters et al., 2014). However, it is not clear whether or not their expectations were being met.

\section{Review findings}

The findings of this thematic synthesis are presented in Table 2. The findings answer research question 3: What are the 'critical situations' where caregivers may be more likely to offer sugary drinks and snacks to infants? Each of the critical situations was inferred from the analytical themes discussed in the results section and summarised in Table 1. This final step involved some interpretative work, as none of the original studies were specifically answering this question. Our confidence in how well the evidence supports each particular finding is reflected in the CERQual assessment of confidence given alongside it. A detailed explanation of how we arrived at our CERQual assessment, stating the reasons for our judgement across each domain (methodological limitations, relevance, adequacy and coherence) is given in Supplemental File 5.

\section{Discussion}

We have identified several 'critical situations' where caregivers may be more likely to offer infants sugary drinks and snacks. Implications for interventions which seek to reduce sugar consumption for the prevention of dental caries will now be explored in more detail.

We identified that caregivers may offer sugary drinks and snacks to infants, as bribes or rewards, in order to manage behavior. This type of feeding has been shown to increase children's preference for and desire to eat the reward foods (Lu, Xiong, Arora, \& Dubé, 2015). As an alternative, effective non-food rewards include verbal praise, non-verbal praise such as smiles or thumbs-up, physical affection and token systems (Fedewa, 2015). Furthermore, an authoritative general parenting style, which is characterised by high warmth and responsiveness and clearly communicated and consistent guidelines for behavior, has been shown to be optimum with regards to the 
management of eating behaviors in children (Pinquart, 2014; Sleddens, Gerards, Thijs, de Vries, \& Kremers, 2011). Families identified as being at high risk of caries should be encouraged to manage behavior in their infants using an authoritative parenting style and non-food based rewards. In some cases, referral to a parenting support programme may be of benefit.

Food culture and family routines were found to be an important influencing factor for caregiver food choices. Nutritional interventions to prevent caries in infants should therefore address the food culture and environment of the whole household, as opposed to the child themselves. This whole family approach has also been shown to be an effective strategy for childhood obesity prevention (Willis, Roberts, Berry, Bryant, \& Rudolf, 2016).

We found that caregivers may be more likely to offer infants sugary drinks and snacks if they perceive them to be underweight or unwell, or conversely, to restrict them if they perceive their child to be at risk of obesity. Overt restriction is defined as that which can be detected by the child(Ogden, Reynolds, \& Smith, 2006) and has been found to increase interest in and desire to consume the restricted food (Brown, 2004; Fisher \& Birch, 1999; Ogden et al., 2006). It is also the feeding behavior most strongly linked to childhood obesity as it teaches children to rely on external cues, rather than hunger, to know when and how much to eat (Pinquart, 2014). Advising caregivers to restrict sugary drinks and snacks specifically for infants identified as being at risk of or already suffering from caries may therefore be counterproductive. This reinforces the idea above that any intervention must address the household food environment, rather than the diet of a specific child.

It has been proposed that the optimum approach to child feeding is for caregivers to choose 'which' foods are offered as well as 'when' and 'where' those foods will be eaten (Eneli et al., 2015; Satter, 1986; Satter, 1995). The child can then be allowed to have control over 'what' and 'how much', if any, of the offered foods to eat. This is a way of achieving 'covert' restriction (Ogden et al., 2006) which is what happens naturally when caregivers have healthier eating habits and are therefore more likely to model healthier behaviors (Ogden et al., 2006). Offering children a 'guided' choice between two or three healthy options also supports the stated desires of caregivers to encourage the 
development of their child's autonomy and to be responsive to their child's preferences. Interventions to support caregivers to use guided choices, as well as covert rather than overt restriction, may be fruitful for the prevention of caries in infants.

Negative caregiver emotional states, high background stress levels due to competing demands and family dis-harmony were all identified as situations that may increase the likelihood of caregivers offering sugary foods and drinks to infants. Strategies which increase family resilience, including the establishment of family routines, addressing family stress and facilitating effective communication patterns have recently been identified as possible approaches that may be of value in childhood obesity prevention (Halliday, Palma, Mellor, Green, \& Renzaho, 2014) and may also be warranted as interventions to prevent caries.

Caregivers may be more likely to offer infants sugary drinks and snacks when the food environment encourages them to do so. To help make 'healthier choices the easier choice' (Koelen \& Lindström, 2005), caregivers need access to healthy food and drink options that are no more expensive than less healthy options, and are just as convenient. Policy options to address the perverse incentives built into the food system include: taxes on sugar-sweetened beverages (Andreyeva, Chaloupka, \& Brownell, 2011); changes to agricultural subsidies, fruit and vegetable pricing policies (Drewnowski \& Darmon, 2005); restrictions on product placement, regulations on portions sizes and labelling, and limiting marketing to children (Cornelsen, Green, Dangour, \& Smith, 2014).

\section{Limitations and strengths of this thematic synthesis}

There were several limitations to this thematic synthesis. The review was only able to include English language studies, which means that the review findings are less applicable to caregivers in non-English speaking high-income countries. Additionally the search strategy was confined to electronic database searching, as opposed to hand searching or searching grey literature.

The majority of the included studies included low socioeconomic status (SES) groups, which may limit the transferability of some of our findings to higher SES groups. Where a particular finding 
was supported only by studies from low SES groups, we downgraded our CERQual assessment of confidence, due to concerns about the 'adequacy' of the body of evidence that contributed to it.

Another limitation of the review was that the majority of the primary studies were conducted with caregivers of children older than 24 months, and most studies included mothers as opposed to fathers or grandparents. For those findings based solely on studies with caregivers of children older than 24 months, or only on studies with mothers, we again downgraded our CERQual assessment of confidence, due to concerns about the 'relevance' of the body of evidence. However, themes that we considered were only applicable to older children (e.g. TV advertising directed at children) were not taken forwards as critical situations that might affect food choices for infants. Furthermore, most of the themes identified were more or less applicable to caregivers of infants as well as older children, e.g. "caregiver emotions" and "busyness".

The CERQual assessment thus allowed us to use concepts taken from studies with caregivers of older children, but to account for this in a transparent way when producing our findings. This is particularly important when intervention strategies are required, but there little qualitative research available that focuses on the specific group in question. Where our confidence in a 'critical situation' is low, we anticipate that with further expansion of the research base, our finding could change and we would be reluctant at this stage to develop interventions based upon it. Where our confidence in a 'critical situation' is moderate or high, we feel it would be reasonable to develop interventions to help caregivers address the situation.

There are also several strengths to this review. To our knowledge, this is the first systematic review and thematic synthesis that has identified 'critical situations' where caregivers may be more likely to offer sugary drinks and snacks to infants. In order to answer our research questions, we have described the general influences on caregiver food choices for preschoolers, then gone beyond this to compose a list of situations that may offer opportunities for interventions to reduce sugar consumption in infants, before habits and feeding preferences become established. 
We have reported this work according to the 'enhancing transparency in reporting the synthesis of qualitative research' (ENTREQ) statement (Tong et al., 2012). Using the thematic synthesis method (Thomas \& Harden, 2008), we were able to treat all of the results sections of the primary studies as data, which allowed for a deeper exploration of the concepts included in the studies than might be expected when extracting only the themes from a study. Using the CERQual approach to assess our confidence in the findings of the review gave us a rigorous method to follow which encouraged us to be transparent about the limitations of our evidence base (Lewin et al., 2015) and allows the reader to assess whether they agree with our findings. Supplemental File 5, CERQual Judgment Table, gives the full reasoning behind each CERQual assessment.

\section{Implications for future research}

Having identified some of the critical situations in which caregivers are more likely to offer sugary drinks and snacks to infants, it would be valuable to develop interventions that can support caregivers to overcome these critical situations. Implementation intentions, or "if-then" plans offer a concise method of linking critical situations with pre-specified, desirable responses, to create new habits (Armitage, 2007; Gollwitzer \& Sheeran, 2006). They bridge the gap between intention and action by linking critical situations, or cues ("if"), with an associated appropriate response ("then") (Webb \& Sheeran, 2007). An example "if-then" plan for avoiding offering an infant sweets might be; "If [name] has done something well...then...I will reward them using a sticker" (instead of sweets). Ifthen plans have been shown to be effective in improving dietary intake, encouraging smokers to quit, reducing alcohol consumption and increasing physical activity (Hagger \& Luszczynska, 2014). Future research exploring their utility in supporting caregivers to address critical situations related to infant feeding is warranted.

\section{Conclusions}

Using the primary qualitative literature on food choices for pre-school children, this thematic synthesis has identified some of the 'critical situations', or triggers, for caregivers to offer sugary 
drinks and snacks to infants. The results suggest that food choices for infants are not based solely on long-term health goals, but instead on a complex range of factors such as behavior and emotional state, family functioning, work commitments, social and cultural influences and availability of and access to healthier foods. Interventions that seek to reduce sugar intake in infants may be more successful if they provide caregivers with practical support to replace the non-nutritive functions of sugary foods and drinks as opposed to relying on an information-giving approach. 


\section{Acknowledgements}

The review authors gratefully acknowledge the GRADE-CERQual project development group, whose methodology, teaching workshops and resources for authors proved invaluable in helping us to identify our review 'findings' and to assess the confidence that we can place in them. In particular the authors would like to thank Claire Glenton who provided advice and feedback on the development of the review findings and the use of the CERQual methodology.

\section{Competing interests}

No authors have any competing interests

Financial disclosure

No funding was received for this work

\section{Ethics statement}

An ethics statement was not required for this work

\section{Supplemental files}

1: Adherence to 'Enhancing Transparency in Reporting the Synthesis of Qualitative Research' (ENTREQ) Statement.

\section{2: Full Search History}

3: Systematic Search Flow Diagram

4: Summary Table of Included Studies

5: CERQual Judgment Table 


\section{References}

A Horodynski, M., \& Arndt, M. J. (2005). "Eating-together" mealtimes with African-American fathers and their toddlers. Applied Nursing Research : ANR, 18(2), 106-9.

Andreyeva, T., Chaloupka, F. J., \& Brownell, K. D. (2011). Estimating the potential of taxes on sugarsweetened beverages to reduce consumption and generate revenue. Preventive Medicine, 52(6), 413-416.

Armitage, C. J. (2007). Efficacy of a brief worksite intervention to reduce smoking: the roles of behavioral and implementation intentions. Journal of Occupational Health Psychology, 12(4), 376390.

Birch, L. (1998). Development of food acceptance patterns in the first years of life. Proceedings of the Nutrition Society, 617-624.

Birch, L., \& Marlin, D. (1982). I don't like it; I never tried it: Effects of exposure on two-year-old children's food preferences. Appetite, 3(4), 353-360.

Brown, R. (2004). Children's eating attitudes and behavior: a study of the modelling and control theories of parental influence. Health Education Research, 19(3), 261-271.

Carnell, S., Cooke, L., Cheng, R., Robbins, a, \& Wardle, J. (2011). Parental feeding behaviors and motivations. A qualitative study in mothers of UK pre-schoolers. Appetite, 57(3), 665-73.

CASP UK. (2013). Critical Appraisal Skills Programme (CASP). 10 questions to help you make sense of qualitative research. Retrieved December 11, 2014, from http://media.wix.com/ugd/dded87_951541699e9edc71ce66c9bac4734c69.pdf

Cornelsen, L., Green, R., Dangour, A., \& Smith, R. (2014). Why fat taxes won't make us thin. Journal of Public Health (Oxford, England), 37(1), 18-23. 
Drewnowski, A., \& Darmon, N. (2005). The economics of obesity: dietary energy density and energy cost. American Journal of Clinical Nutrition, 82(12), 265-273.

Duncanson, K., \& Burrows, T. (2013). Parents' Perceptions of Child Feeding: A Qualitative Study Based on the Theory of Planned Behavior. Journal of Developmental \& Behavioral Pediatrics, 34(4), 227236.

Eneli, I. U., Tylka, T. L., Watowicz, R. P., Hummel, J., Ritter, J., \& Lumeng, J. C. (2015). Targeting Feeding and Eating Behaviors : Development of the Feeding Dynamic Intervention for Caregivers of 2- to 5-Year-Old Children. Journal of Obesity.

Fedewa, A. L. (2015). How Food as a Reward Is Detrimental to Children 's Health, Learning , and Behavior. Journal of School Health, 85(9).

Fisher, J. O., \& Birch, L. L. (1999). Restricting access to palatable foods affects children's behavioral response, food selection, and intake. Am J Clin Nutr, 69(6), 1264-1272.

Freeman, R., Ekins, R., \& Oliver, M. (2005). Doing Best for Children: An emerging grounded theory of parents' policing strategies to regulate between-meal snacking. Grounded Theory Review, 4(3), Online. Retrieved November 13, 2014 from http://groundedtheoryreview.com/2005/06/22/1513/

Freeman, R., \& Stevens, A. (2008). Nursing caries and buying time: an emerging theory of prolonged bottle feeding. Community Dentistry and Oral Epidemiology, 36(5), 425-33.

Glaser, B., \& Strauss, A. (1967). The Discovery of Grounded Theory: Strategies for Qualitative Research. New York: Aldine Publishing Co.

Gollwitzer, P. M. (1999). Implementation Intentions: Strong effects of simple plans. American Psychologist, 54(7), 493-503. 
Gollwitzer, P. M., \& Sheeran, P. (2006). Implementation Intentions and Goal Achievement: A Metaanalysis of Effects and Processes. Advances in Experimental Social Psychology.

Hagger, M. S., \& Luszczynska, A. (2014). Implementation Intention and Action Planning Interventions in Health Contexts : State of the Research and Proposals for the Way Forward. Applied Psychology Health and Wellbeing, 6(1), 1-47.

Halliday, J. A, Palma, C. L., Mellor, D., Green, J., \& Renzaho, A.M.N. (2014). The relationship between family functioning and child and adolescent overweight and obesity: a systematic review. International Journal of Obesity, 38(4), 480-493.

Herman, A. N., Malhotra, K., Wright, G., Fisher, J. O., \& Whitaker, R. C. (2012). A qualitative study of the aspirations and challenges of low-income mothers in feeding their preschool-aged children. The International Journal of Behavioral Nutrition and Physical Activity, 9(1), 132.

Hildebrand, D. a., \& Shriver, L. H. (2010). A Quantitative and Qualitative Approach to Understanding Fruit and Vegetable Availability in Low-Income African-American Families with Children Enrolled in an Urban Head Start Program. Journal of the American Dietetic Association, 110(5),

Horodynski, M. a, Brophy-Herb, H., Henry, M., Smith, K. a, \& Weatherspoon, L. (2009). Toddler feeding: Expectations and experiences of low-income African American mothers. Health Education Journal, 68(1), 14-25. http://doi.org/10.1177/0017896908100445

Hughes, C. C., Sherman, S. N., \& Whitaker, R. C. (2010). How low-income mothers with overweight preschool children make sense of obesity. Qualitative Health Research, 20(4), 465-78.

Kalinowski, A., Krause, K., Berdejo, C., Harrell, K., Rosenblum, K., \& Lumeng, J. C. (2012). Beliefs about the role of parenting in feeding and childhood obesity among mothers of lower socioeconomic status. Journal of Nutrition Education and Behavior, 44(5), 432-7. 
Koelen, M. A, \& Lindström, B. (2005). Making healthy choices easy choices: the role of empowerment. European Journal of Clinical Nutrition, 59 Suppl 1, S10-5; discussion S16, S23.

Lewin, S., Glenton, C., Munthe-Kaas, H., Carlsen, B., Colvin, C. J., Gülmezoglu, M., ... Rashidian, A. (2015). Using Qualitative Evidence in Decision Making for Health and Social Interventions: An Approach to Assess Confidence in Findings from Qualitative Evidence Syntheses (GRADE-CERQual). PLOS Medicine, 12(10), e1001895.

Lindsay, A. C., Sussner, K. M., Greaney, M. L., \& Peterson, K. E. (2009). Influence of social context on eating, physical activity, and sedentary behaviors of Latina mothers and their preschool-age children. Health Education \& Behavior : The Official Publication of the Society for Public Health Education, 36(1), 81-96.

Lindsay, A. C., Sussner, K. M., Greaney, M. L., \& Peterson, K. E. (2010). Latina mothers' beliefs and practices related to weight status, feeding, and the development of child overweight. Public Health Nursing, 28(2), 107-18.

Lu, J., Xiong, S., Arora, N., \& Dubé, L. (2015). Using food as reinforcer to shape children's non-food behavior: The adverse nutritional effect doubly moderated by reward sensitivity and gender. Eating Behaviors, 19, 94-97.

Maxwell, J. a. (2010). What Is Realism, and Why Should Qualitative Researchers Care? A Realist Approach for Qualitative Research, 3-13.

Mc Master University. (2014). Search strategies for PSYCHinfo in OVID syntax. Retrieved October 15, 2014, from http://hiru.mcmaster.ca/hiru/HIRU_Hedges_PsycINFO_Strategies.aspx

McMaster University. (2014). Search filters for MEDLINE in OVID syntax and the PubMed translation. Retrieved October 22, 2014, from http://hiru.mcmaster.ca/hiru/HIRU_Hedges_MEDLINE_Strategies.aspx 
Mennella, J. a, \& Trabulsi, J. C. (2012). Complementary foods and flavor experiences: setting the foundation. Annals of Nutrition \& Metabolism, 60 Suppl 2(suppl 2), 40-50.

Moore, S. N., Tapper, K., \& Murphy, S. (2010). Feeding goals sought by mothers of 3-5-year-old children. British Journal of Health Psychology, 15(Pt 1), 185-96.

Morenga, L. Te, Mallard, S., \& Mann, J. (2013). Dietary sugars and body weight: systematic review and meta-analyses of randomised controlled trials and cohort studies. BMJ: British Medical Journal, 7492(January), 1-25.

Moynihan, P. J., \& Kelly, S. A. M. (2014). Effect on Caries of Restricting Sugars Intake: Systematic Review to Inform WHO Guidelines. Journal of Dental Research, 93(1), 8-18.

Nielsen, A., Michaelsen, K. F., \& Holm, L. (2013). Parental concerns about complementary feeding: differences according to interviews with mothers with children of 7 and 13 months of age. European Journal of Clinical Nutrition, 67(11), 1157-1162.

Ogden, J., Reynolds, R., \& Smith, A. (2006). Expanding the concept of parental control: a role for overt and covert control in children's snacking behavior? Appetite, 47(1), 100-6.

Omar, M. A., Coleman, G., \& Hoerr, S. (2010). Healthy Eating for Rural Low-Income Toddlers : Caregivers ' Perceptions. Journal of Community Health Nursing, 18(2), 37-41.

Orbell, S., Hodgkins, S., \& Sheeran, P. (1997). Implementation intentions and the theory of planned behavior. Personality and Social Psychology Bulletin, 23, 945-954.

Pagnini, D. L., Wilkenfeld, R. L., King, L. A, Booth, M. L., \& Booth, S. L. (2007). Mothers of pre-school children talk about childhood overweight and obesity: The Weight Of Opinion Study. Journal of Paediatrics and Child Health, 43(12), 806-10. 
Peerbhay, F. B. (2009). Compliance with preventive care following dental treatment of children under general anaesthesia. SADJ, 64, 442-445.

Peters, J., Parletta, N., Lynch, J., \& Campbell, K. (2014). A comparison of parental views of their preschool children's "healthy" versus "unhealthy" diets. A qualitative study. Appetite, 76, 129-136.

Peters, J., Sinn, N., Campbell, K., \& Lynch, J. (2012). Parental influences on the diets of 2-5-year-old children: systematic review of interventions. Early Child Development and Care, 182(7), 837-857.

Pinquart, M. (2014). Associations of General Parenting and Parent - Child Relationship With Pediatric Obesity : A Meta-Analysis. Journal of Pediatric Psychology, 1-13.

Satter, E. (1995). Feeding dynamics: helping children to eat well. Journal of Pediatric Health Care : Official Publication of National Association of Pediatric Nurse Associates \& Practitioners, 9(4), 17884.

Satter, E. M. (1986). The feeding relationship. J Am Diet Assoc, 86(3), 352-356.

Scientific Advisory Committee on Nutrition. (2015). Carbohydrates and Health. (Scientific Advisory Committee on Nutrition, Ed.). London: The Stationary Office.

Sheiham, A., \& James, W. P. T. (2014). A reappraisal of the quantitative relationship between sugar intake and dental caries: the need for new criteria for developing goals for sugar intake. $B M C$ Public Health, 14(1), 863.

Sleddens, E. F. C., Gerards, S. M. P. L., Thijs, C., de Vries, N. K., \& Kremers, S. P. J. (2011). General parenting, childhood overweight and obesity-inducing behaviors: a review. International Journal of Pediatric Obesity : IJPO : An Official Journal of the International Association for the Study of Obesity, 6(2-2), e12-27. 
The Joanna Briggs Institute. (2014). Reviewers' Manual. Adelaide. Retrieved September 21, 2014, from http://joannabriggs.org/assets/docs/sumari/reviewersmanual-2014.pdf

The World Bank. (2014). Country and lending groups: High income. Retrieved October 8, 2015, from http://data.worldbank.org/about/country-and-lending-groups\#High_income

Thomas, J., \& Harden, A. (2008). Methods for the thematic synthesis of qualitative research in systematic reviews. BMC Medical Research Methodology, 8, 45.

Tipton, J. A. (2014). Caregivers' psychosocial factors underlying sugar-sweetened beverage intake among non-Hispanic black preschoolers: an elicitation study. Journal of Pediatric Nursing, 29(1), 47-57.

Tong, A., Flemming, K., McInnes, E., Oliver, S., \& Craig, J. (2012). Enhancing transparency in reporting the synthesis of qualitative research: ENTREQ. BMC Medical Research Methodology, 12(1), 181.

Urquhart, C. (2013). Chapter 5: Coding and Conceptualizing. In Grounded Theory for Qualitative Research: A practical guide (pp. 78-105). London: Sage.

Ventura, A. K., \& Mennella, J. A. (2011). Innate and learned preferences for sweet taste during childhood. Current Opinion in Clinical Nutrition and Metabolic Care, 14, 379-384.

Webb, T. L., \& Sheeran, P. (2007). How do implementation intentions promote goal attainment? A test of component processes. Journal of Experimental Social Psychology, 43(2), 295-302.

Willis, T. A., Roberts, K. P. J., Berry, T. M., Bryant, M., \& Rudolf, M. C. J. (2016). The impact of HENRY on parenting and family lifestyle: A national service evaluation of a preschool obesity prevention programme. Public Health, 136(0), 101-108. 
World Cancer Research Fund International. (2015). Curbing global sugar consumption. World Cancer Research Fund International. Retrieved from http://www.wcrf.org/sites/default/files/CurbingGlobal-Sugar-Consumption.pdf

World Health Organisation. (2015). WHO/ Guideline Sugars intake for adults and children. Geneva. 
Table 1: Analytical Theme Structure

\begin{tabular}{|c|c|c|}
\hline Third order & Second order & First order \\
\hline $\begin{array}{l}\text { Child centred } \\
\text { factors }\end{array}$ & $\begin{array}{l}\text { Behaviour management } \\
\text { Socialization of the child } \\
\text { Promotion of child health }\end{array}$ & $\begin{array}{l}\text { Bribery and distraction } \\
\text { Rewards and treats } \\
\text { Family food culture } \\
\text { Encouraging autonomy } \\
\text { Teaching restraint } \\
\text { Special occasions } \\
\text { Food for pleasure } \\
\text { Perception of child health risks }\end{array}$ \\
\hline
\end{tabular}

http://mc.manuscriptcentral.com/qhr 


\section{Page 37 of 64}

\section{Qualitative Health Research}

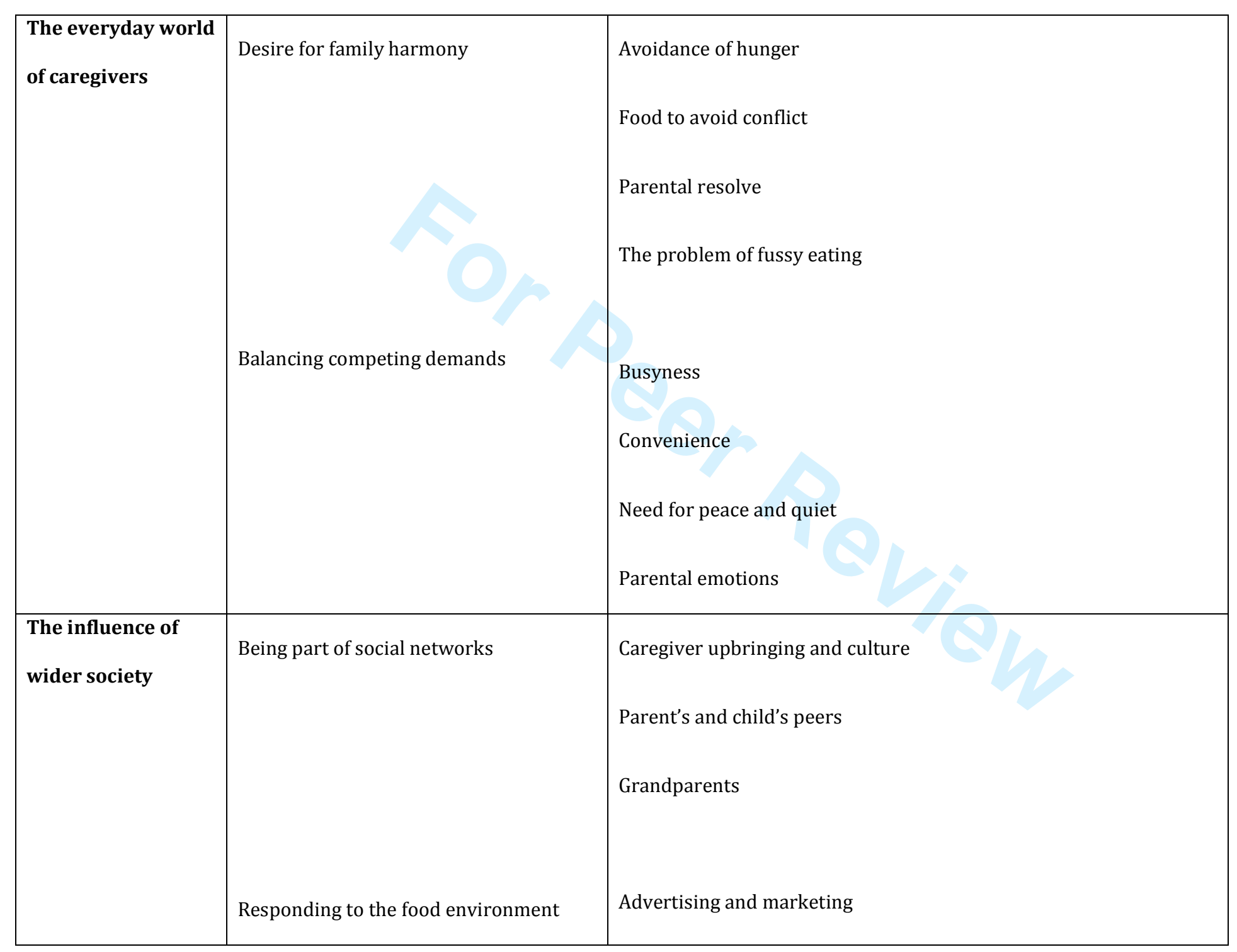

http://mc.manuscriptcentral.com/qhr 


\begin{tabular}{|l|l|l|}
\hline & Availability and access \\
& Food costs \\
& Expectation of health promoting childcare \\
\hline
\end{tabular}


Table 2: Review Findings

\begin{tabular}{|l|l|l|l|}
\hline $\begin{array}{l}\text { 'Critical situations' where caregivers may } \\
\text { be more likely to offer sugary drinks and } \\
\text { snacks to infants }\end{array}$ & $\begin{array}{l}\text { Overall CERQual } \\
\text { assessment of } \\
\text { confidence }\end{array}$ & \begin{tabular}{l} 
Explanation for CERQual assessment of confidence \\
\hline Child-centred factors
\end{tabular} & Studies contributing to finding \\
\hline $\begin{array}{l}\text { Behaviour management: } \\
\text { Caregivers may be more likely to offer sweet } \\
\text { drinks and snacks in situations where an } \\
\text { infant is upset, bored, or is seen as deserving } \\
\text { a reward or a 'treat'. }\end{array}$ & Moderate & $\begin{array}{l}\text { Graded as moderate confidence because of some } \\
\text { concerns about relevance, minor methodological } \\
\text { limitations and minor concerns about adequacy. }\end{array}$ & $\begin{array}{l}\text { (A Horodynski \& Arndt, 2005; } \\
\text { Carnell et al., 2011; Hughes et al., } \\
\text { 2010; Lindsay et al., 2009, 2010; }\end{array}$ \\
\hline
\end{tabular}




\begin{tabular}{|c|c|c|c|}
\hline $\begin{array}{l}\text { Socialization of the child: Caregivers may } \\
\text { be more likely to offer sweet drinks and } \\
\text { snacks to infants during special occasions } \\
\text { and celebrations, or if sugary foods are seen } \\
\text { as part of the 'food culture' of the family. }\end{array}$ & Moderate & $\begin{array}{l}\text { Graded as moderate confidence because of moderate } \\
\text { methodological limitations, and minor concerns about } \\
\text { relevance and adequacy. }\end{array}$ & $\begin{array}{l}9 \text { studies } \\
\text { (A Horodynski \& Arndt, 2005; } \\
\text { Carnell et al., 2011; Duncanson \& } \\
\text { Burrows, 2013; Herman et al., } \\
\text { 2012; Horodynski et al., 2009; } \\
\text { Kalinowski et al., 2012; Lindsay et } \\
\text { al., 2009; Nielsen et al., 2013; } \\
\text { Peters et al., 2014) }\end{array}$ \\
\hline $\begin{array}{l}\text { Promotion of child health: Caregivers may } \\
\text { be more likely to offer sugary drinks and } \\
\text { snacks to infants if they perceive that the } \\
\text { infant is unwell, or has a history of being } \\
\text { underweight or low birth weight. }\end{array}$ & Moderate & $\begin{array}{l}\text { Graded as moderate confidence because of some } \\
\text { concerns about relevance, minor concerns about } \\
\text { adequacy and minor methodological limitations }\end{array}$ & $\begin{array}{l}5 \text { studies } \\
\text { (Carnell et al., 2011; Duncanson \& } \\
\text { Burrows, 2013; Lindsay et al., } \\
\text { 2010; Omar et al., 2010; Pagnini et } \\
\text { al., 2007) }\end{array}$ \\
\hline
\end{tabular}




\begin{tabular}{|c|c|c|c|}
\hline $\begin{array}{l}\text { Desire for family harmony: } \\
\text { Caregivers may be more likely to offer sugary } \\
\text { drinks and snacks if infants are disturbing } \\
\text { other members of the family, or are } \\
\text { disrupting family routines due to crying, } \\
\text { hunger or food refusals. This may be more } \\
\text { important in families with higher levels of } \\
\text { existing dis-harmony. }\end{array}$ & Moderate & $\begin{array}{l}\text { Graded as moderate confidence because of moderate } \\
\text { methodological limitations and some concerns about } \\
\text { relevance. }\end{array}$ & $\begin{array}{l}11 \text { studies } \\
\text { (A Horodynski \& Arndt, 2005; } \\
\text { Carnell et al., 2011; Duncanson \& } \\
\text { Burrows, 2013; Freeman \& } \\
\text { Stevens, 2008; Herman et al., } \\
\text { 2012; Hughes et al., 2010; Moore } \\
\text { et al., 2010; Nielsen et al., 2013; } \\
\text { Omar et al., 2010; Peters et al., } \\
\text { 2014; Tipton, 2014) }\end{array}$ \\
\hline $\begin{array}{l}\text { Competing demands: } \\
\text { Caregivers may be more likely to offer infants } \\
\text { sugary drinks and snacks when they are } \\
\text { busy, tired, rushed, or struggling to cope with } \\
\text { negative emotions. This may become more } \\
\text { important if caregivers are coping with } \\
\text { negative emotions and difficult life } \\
\text { circumstances in general. }\end{array}$ & High & $\begin{array}{l}\text { Graded as high confidence because there were only } \\
\text { minor methodological limitations and minor concerns } \\
\text { about relevance. }\end{array}$ & $\begin{array}{l}13 \text { studies } \\
\text { (A Horodynski \& Arndt, 2005; } \\
\text { Carnell et al., 2011; Duncanson \& } \\
\text { Burrows, 2013; Freeman \& } \\
\text { Stevens, 2008; Herman et al., } \\
\text { 2012; Hildebrand \& Shriver, 2010; } \\
\text { Hughes et al., 2010; Kalinowski et } \\
\text { al., 2012; Lindsay et al., 2009; } \\
\text { Moore et al., 2010; Nielsen et al., } \\
\text { 2013; Omar et al., 2010; Peters et } \\
\text { al., 2014; Tipton, 2014) }\end{array}$ \\
\hline
\end{tabular}




\section{Wider society}

Being part of social networks:

Caregivers may be more likely to offer sugary

drinks and snacks to infants, when

encouraged to do so by other family

members, or if other children are consuming

them. This may be of greater relevance

where the culture of the family views food as

an expression of love, or where there is a

recent cultural memory of food insecurity.
Graded as high confidence because there were only minor methodological limitations and minor concerns about relevance.

\section{Graded as low confidence because of moderate} methodological limitations and substantial concerns about relevance and adequacy.
12 studies (Carnell et al., 2011; Duncanson \& Burrows, 2013; Herman et al., 2012; Horodynski et al., 2009; Hughes et al., 2010; Kalinowski et al., 2012; Lindsay et al., 2009, 2010; Moore et al., 2010 Omar et al., 2010; Pagnini et al., 2007; Peters et al., 2014; Tipton, 2014)

\section{3 studies}

Caregivers who have memories of sugary Low drinks and snacks being restricted when they were children may be more likely to offer sugary drinks and snacks to their infants.
(Herman et al., 2012; Kalinowski et al., 2012; Moore et al., 2010) 


\begin{tabular}{l|l|l|l|}
$\begin{array}{l}\text { Responding to the food environment: } \\
\text { Caregivers may be more likely to offer infants } \\
\text { sugary drinks and snacks in situations where } \\
\text { they don't have access to convenient } \\
\begin{array}{l}\text { alternatives, such as fruit or water, at a } \\
\text { reasonable or no extra cost }\end{array}\end{array}$ & Moderate & $\begin{array}{l}\text { Graded as moderate confidence because of moderate } \\
\text { methodological limitations, some concerns about } \\
\text { adequacy and minor concerns about relevance. }\end{array}$ & $\begin{array}{l}\text { 8 studies (Carnell et al., 2011; } \\
\text { Hildebrand \& Shriver, 2010; } \\
\text { Horodynski et al., 2009; Lindsay et } \\
\text { al., 2009; Omar et al., 2010; } \\
\text { Pagnini et al., 2007; Peters et al., } \\
\text { 2012; Tipton, 2014) }\end{array}$ \\
\hline
\end{tabular}




\begin{tabular}{|c|c|c|c|}
\hline & Item & Guide and description & $\begin{array}{l}\text { Where } \\
\text { addressed }\end{array}$ \\
\hline 1 & Aim & State the research question the synthesis addresses. & $\mathrm{P} 2$ and 3 \\
\hline 2 & $\begin{array}{l}\text { Synthesis } \\
\text { methodology }\end{array}$ & $\begin{array}{l}\text { Identify the synthesis methodology or theoretical framework which underpins the synthesis, and describe the } \\
\text { rationale for choice of methodology (e.g. meta-ethnography, thematic synthesis, critical interpretive synthesis, } \\
\text { grounded theory synthesis, realist synthesis, meta-aggregation, meta-study, framework synthesis). }\end{array}$ & $\begin{array}{l}\text { P4 } \\
\text { P7-8 }\end{array}$ \\
\hline 3 & $\begin{array}{l}\text { Approach to } \\
\text { searching }\end{array}$ & $\begin{array}{l}\text { Indicate whether the search was pre-planned (comprehensive search strategies to seek all available studies) or } \\
\text { iterative (to seek all available concepts until they theoretical saturation is achieved). }\end{array}$ & P5 \\
\hline 4 & $\begin{array}{l}\text { Inclusion } \\
\text { criteria }\end{array}$ & $\begin{array}{l}\text { Specify the inclusion/exclusion criteria (e.g. in terms of population, language, year limits, type of publication, study } \\
\text { type). }\end{array}$ & P4 \\
\hline 5 & Data sources & $\begin{array}{l}\text { Describe the information sources used (e.g. electronic databases (MEDLINE, EMBASE, CINAHL, psycINFO, Econlit), } \\
\text { grey literature databases (digital thesis, policy reports), relevant organizational websites, experts, information } \\
\text { specialists, generic web searches (Google Scholar) hand searching, reference lists) and when the searches } \\
\text { conducted; provide the rationale for using the data sources. }\end{array}$ & P5 \\
\hline 6 & $\begin{array}{l}\text { Electronic } \\
\text { Search } \\
\text { strategy }\end{array}$ & $\begin{array}{l}\text { Describe the literature search (e.g. provide electronic search strategies with population terms, clinical or health topic } \\
\text { terms, experiential or social phenomena related terms, filters for qualitative research, and search limits). }\end{array}$ & $\begin{array}{l}\text { Additional } \\
\text { file A2 }\end{array}$ \\
\hline 7 & $\begin{array}{l}\text { Study } \\
\text { screening } \\
\text { methods }\end{array}$ & $\begin{array}{l}\text { Describe the process of study screening and sifting (e.g. title, abstract and full text review, number of independent } \\
\text { reviewers who screened studies). }\end{array}$ & $\begin{array}{l}\text { P5 and } \\
\text { Figure } 1\end{array}$ \\
\hline 8 & $\begin{array}{l}\text { Study } \\
\text { characteristics }\end{array}$ & $\begin{array}{l}\text { Present the characteristics of the included studies (e.g. year of publication, country, population, number of } \\
\text { participants, data collection, methodology, analysis, research questions). }\end{array}$ & $\begin{array}{l}\text { Additional } \\
\text { table A3 }\end{array}$ \\
\hline 9 & $\begin{array}{l}\text { Study } \\
\text { selection } \\
\text { results }\end{array}$ & $\begin{array}{l}\text { Identify the number of studies screened and provide reasons for study exclusion (E,g., for comprehensive searching, } \\
\text { provide numbers of studies screened and reasons for exclusion indicated in a figure/flowchart; for iterative } \\
\text { searching describe reasons for study exclusion and inclusion based on modifications to the research question and/or } \\
\text { contribution to theory development). }\end{array}$ & Figure 1 \\
\hline 10 & $\begin{array}{l}\text { Rationale for } \\
\text { appraisal }\end{array}$ & $\begin{array}{l}\text { Describe the rationale and approach used to appraise the included studies or selected findings (e.g. assessment of } \\
\text { conduct (validity and robustness), assessment of reporting (transparency), and assessment of content and utility of } \\
\text { the findings). }\end{array}$ & P8 \\
\hline
\end{tabular}




\begin{tabular}{|c|c|c|c|}
\hline 11 & $\begin{array}{l}\text { Appraisal } \\
\text { items }\end{array}$ & $\begin{array}{l}\text { State the tools, frameworks and criteria used to appraise the studies or selected findings (e.g. Existing tools: CASP, } \\
\text { QARI, COREQ, Mays and Pope [25]; reviewer developed tools; describe the domains assessed: research team, study } \\
\text { design, data analysis and interpretations, reporting). }\end{array}$ & P8 \\
\hline 12 & $\begin{array}{l}\text { Appraisal } \\
\text { process }\end{array}$ & $\begin{array}{l}\text { Indicate whether the appraisal was conducted independently by more than one reviewer and if consensus was } \\
\text { required. }\end{array}$ & P6 \\
\hline 13 & $\begin{array}{l}\text { Appraisal } \\
\text { results }\end{array}$ & $\begin{array}{l}\text { Present results of the quality assessment and indicate which articles, if any, were weighted/excluded based on the } \\
\text { assessment and give the rationale. }\end{array}$ & $\begin{array}{l}\text { Additional } \\
\text { file: A3 }\end{array}$ \\
\hline 14 & $\begin{array}{l}\text { Data } \\
\text { extraction }\end{array}$ & $\begin{array}{l}\text { Indicate which sections of the primary studies were analyzed and how were the data extracted from the primary } \\
\text { studies? (E.g. all text under the headings "results /conclusions" were extracted electronically and entered into a } \\
\text { computer software). }\end{array}$ & P6 \\
\hline 15 & Software & State the computer software used, if any. & P6 \\
\hline 16 & $\begin{array}{l}\text { Number of } \\
\text { reviewers }\end{array}$ & Identify who was involved in coding and analysis & P6-8 \\
\hline 17 & Coding & Describe the process for coding of data (e.g. line by line coding to search for concepts). & P6-7 \\
\hline 18 & $\begin{array}{l}\text { Study } \\
\text { comparison }\end{array}$ & $\begin{array}{l}\text { Describe how were comparisons made within and across studies (e.g. subsequent studies were coded into pre- } \\
\text { existing concepts, and new concepts were created when deemed necessary). }\end{array}$ & P7 \\
\hline 19 & $\begin{array}{l}\text { Derivation of } \\
\text { themes }\end{array}$ & Explain whether the process of deriving the themes or constructs was inductive or deductive & P7 \\
\hline 20 & Quotations & $\begin{array}{l}\text { Provide quotations from the primary studies to illustrate themes/constructs, and identify whether the quotations } \\
\text { were participant quotations of the author's interpretation. }\end{array}$ & $\begin{array}{l}\text { P12-26 } \\
\text { Indicated by: } \\
\text { "participant } \\
\text { quotation'" } \\
\text { or "author's } \\
\text { interpretatio } \\
\text { n" }\end{array}$ \\
\hline 21 & $\begin{array}{l}\text { Synthesis } \\
\text { output }\end{array}$ & $\begin{array}{l}\text { Present rich, compelling and useful results that go beyond a summary of the primary studies (e.g. new } \\
\text { interpretation, models of evidence, conceptual models, analytical framework, development of a new theory or } \\
\text { construct). }\end{array}$ & $\begin{array}{l}\text { P27 review } \\
\text { findings }\end{array}$ \\
\hline
\end{tabular}




\section{Additional file 1: Adherence to 'enhancing transparency in reporting the synthesis of qualitative research' (ENTREQ) statement}

1. Tong A, Flemming K, McInnes E, Oliver S, Craig J. Enhancing transparency in reporting the synthesis of qualitative research: ENTREQ. BMC Med Res Methodol [Internet]. BMC Medical Research Methodology; 2012 Jan [cited 2014 Sep 15];12(1):181. Available from:

http://www.pubmedcentral.nih.gov/articlerender.fcgi?artid=3552766\&tool=pmcentrez\&rendertype=abstract 


\section{Additional file 2: Full search history}

\section{Social Policy and Practice database}

1 (mother or grandmother or grandfather or father or parent* or carer or care-giver or care giver or legal guardian

or foster $\left.{ }^{\star}\right) . \mathrm{mp}$. [mp=abstract, title, publication type, heading word, accession number] (57120)

2 (infant or child or pre-school or pre school or toddler or neonate or newborn).mp. [mp=abstract, title,

publication type, heading word, accession number] (69674)

3 (Food or feeding or food choice or eat* or weaning or complementary feeding or sweets or sugar* or snack* or

drink $^{*}$ ).mp. [mp=abstract, title, publication type, heading word, accession number] (7742)

4 (influence or motiv* or aspiration* or challenge* or belief* or aim* or hope* or difficult* or trigger* or

benefit* or choice or choose).mp. [mp=abstract, title, publication type, heading word, accession number] (121009)

$5 \quad 1$ and 12 and 3 and 4 (281)

6 qualitative.mp. or Qualitative Research/ (9239)

75 and $6(16)$

\section{Applied Social Sciences Index and Abstracts (ASSIA)}

\section{Set\# Searched for}

Databases

Results

\begin{tabular}{|c|c|c|}
\hline S2 & $\begin{array}{l}\text { (mother OR grandmother } \\
\text { OR grandfather OR father } \\
\text { OR parent* OR carer OR } \\
\text { care-giver OR care giver OR } \\
\text { legal guardian OR foster*) } \\
\text { AND (food OR feeding OR } \\
\text { food choice OR eat* OR } \\
\text { weaning OR complementary } \\
\text { feeding OR sweets OR } \\
\text { sugar* OR snack* OR } \\
\text { drink*) AND (influence OR }^{*} \text { motiv* OR aspiration* OR } \\
\text { challenge* OR belief OR }^{*} \text { Oim* OR hope* OR difficult* } \\
\text { OR trigger OR benefit* OR } \\
\text { choice OR choose) AND } \\
\text { qualitative AND schol(yes) } \\
\text { AND la.exact("ENG") }\end{array}$ & $\begin{array}{lll}\text { Applied } & \text { Social } & \text { Sciences } \\
\text { Index } & \text { and } & \text { Abstracts } \\
\text { (ASSIA) } & & \end{array}$ \\
\hline
\end{tabular}


Additional file 2: Full search history

\section{PsycINFO}

Database: PsycINFO <1806 to October Week 3 2014>

Search Strategy:

1 (paren* or mother or father or grandmother or grandfather or grandparent or guardian or foster).mp. [mp=title,

abstract, heading word, table of contents, key concepts, original title, tests \& measures] (282133)

2 (Infant or child or pre-school or toddler or weaning).mp. [mp=title, abstract, heading word, table of contents, key concepts, original title, tests \& measures] (295536)

3 (food or feeding or infant feeding or weaning or food choice* or complementary feeding or snack* or sugar or

drink $^{*}$ ).mp. [mp=title, abstract, heading word, table of contents, key concepts, original title, tests \& measures]

$(126254)$

$4 \quad 1$ and 2 and 3 (5691)

5 (Influenc* or motivation or aspiration* or aim or belief* or hope* or reward* or benefit* or difficult* or trigger*).mp. [mp=title, abstract, heading word, table of contents, key concepts, original title, tests \& measures]

(945333)

64 and 5 (2266)

\section{Medline}

Database: Ovid MEDLINE(R) <1946 to October Week 5 2014>

Search Strategy:

1 (mother or grandmother or grandfather or father or parent* or carer or care-giver or care giver or legal guardian

or foster*).mp. [mp=title, abstract, original title, name of substance word, subject heading word, keyword heading word,

protocol supplementary concept word, rare disease supplementary concept word, unique identifier] (449216)

2 (infant or child or pre-school or pre school or toddler or neonate or newborn).mp. $[\mathrm{mp}=$ title, abstract, original

title, name of substance word, subject heading word, keyword heading word, protocol supplementary concept word, rare

disease supplementary concept word, unique identifier] (2310580)

3 (Food or feeding or food choice or eat* or weaning or complementary feeding or sweets or sugar* or snack* or

drink $^{*}$ ).mp. [mp=title, abstract, original title, name of substance word, subject heading word, keyword heading word, protocol supplementary concept word, rare disease supplementary concept word, unique identifier] (797824) 


\section{Additional file 2: Full search history}

4 (influence or motiv* or aspiration* or challenge* or belief* or aim* or hope* or difficult* or trigger* or

benefit $^{\star}$ or choice or choose).mp. [mp=title, abstract, original title, name of substance word, subject heading word,

keyword heading word, protocol supplementary concept word, rare disease supplementary concept word, unique identifier]

(3174227)

$5 \quad 1$ and 2 and 3 and 4 (8785)

6 qualitative.mp. or Qualitative Research/ (123770)

$7 \quad 5$ and 6 (432) 
Figure 1: Systematic search flow diagram

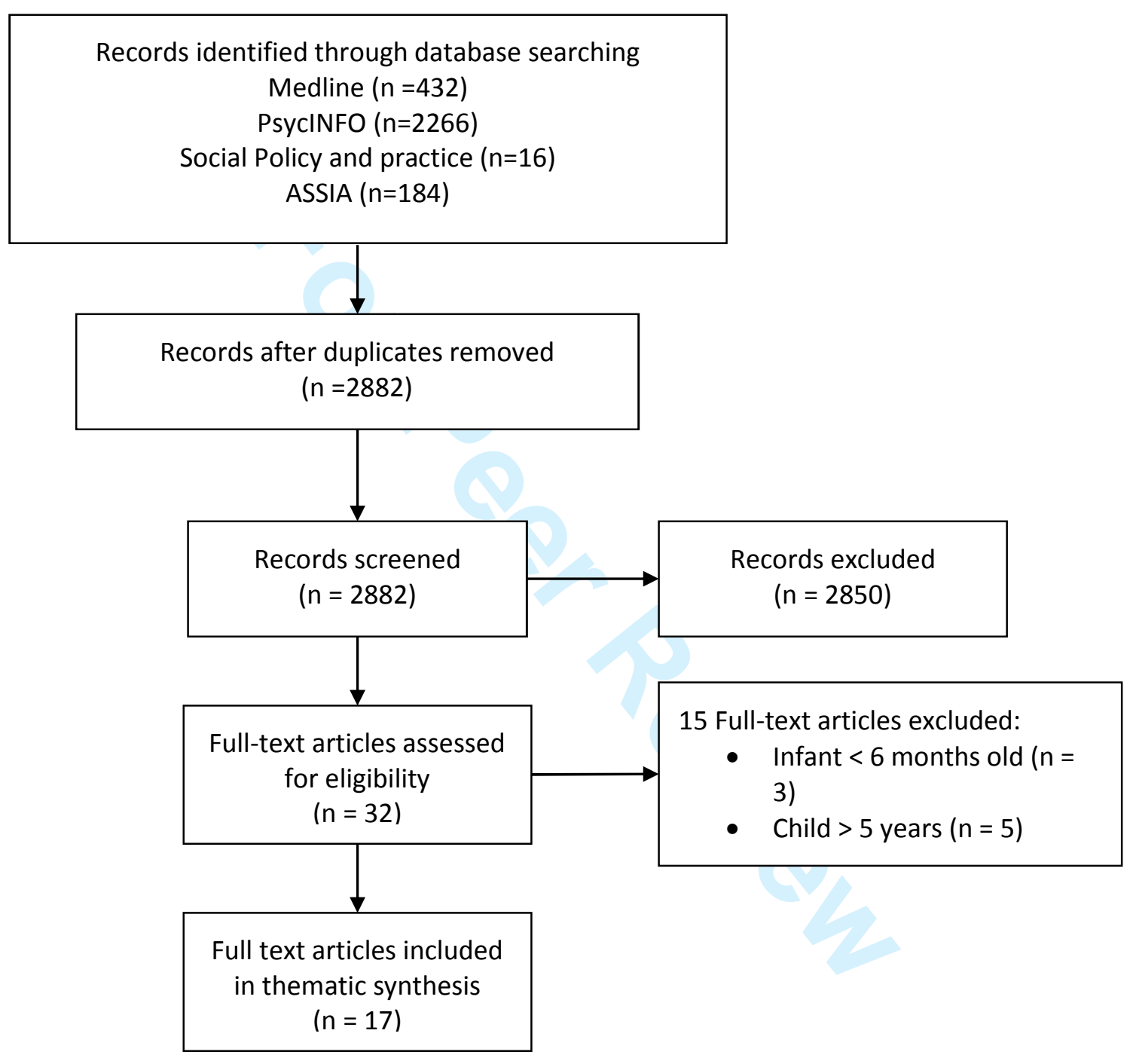


Additional file 3: Summary table of included studies

\begin{tabular}{|c|c|c|c|c|c|}
\hline Citation & Location & Sample & $\begin{array}{l}\text { Data collection and } \\
\text { analysis }\end{array}$ & $\begin{array}{l}\text { Main themes / findings related } \\
\text { to review question }\end{array}$ & $\begin{array}{l}\text { Methodological } \\
\text { quality }\end{array}$ \\
\hline $\begin{array}{l}\text { (Hughes, } \\
\text { Sherman, \& } \\
\text { Whitaker, } \\
\text { 2010) }\end{array}$ & Kentucky, US & $\begin{array}{l}21 \text { mothers of } \\
\text { overweight pre- } \\
\text { school children (30- } \\
60 \text { months). } \\
\text { Low SES. } \\
14 \text { White, } 7 \text { African } \\
\text { American, and all } \\
\text { non-Hispanic }\end{array}$ & $\begin{array}{l}\text { Semi-structured } \\
\text { interviews. } \\
\text { Analysis methods } \\
\text { not stated but } \\
\text { description sounds } \\
\text { like thematic } \\
\text { analysis }\end{array}$ & $\begin{array}{l}\text { "(a) Nature vs. nurture, (b) } \\
\text { medical authority vs. lived } \\
\text { experience, and (c) relieving } \\
\text { immediate stress vs. preventing } \\
\text { long-term consequences." }\end{array}$ & High \\
\hline $\begin{array}{l}\text { (Omar, } \\
\text { Coleman, \& } \\
\text { Hoerr, 2010) }\end{array}$ & $\begin{array}{l}3 \text { rural } \\
\text { Michigan } \\
\text { counties, US }\end{array}$ & $\begin{array}{l}20 \text { caregivers of } \\
\text { "toddlers" (11 } \\
\text { fathers, } 1 \\
\text { boyfriend, } \\
6 \text { mothers, } 1 \\
\text { grandmother, and } 1 \\
\text { aunt). } \\
\text { Low SES. } \\
17 \text { were White and } \\
2 \text { Hispanic, } 1 \\
\text { African American }\end{array}$ & $\begin{array}{l}3 \text { Focus groups } \\
\text { Analysis methods } \\
\text { not stated but in the } \\
\text { results section } \\
\text { refers to 'content } \\
\text { analysis' }\end{array}$ & $\begin{array}{l}\text { "Four major themes emerged:(a) } \\
\text { Barriers to providing healthy } \\
\text { meals, (b) division of } \\
\text { responsibility, (c) mealtime } \\
\text { behavior, and (d) desired } \\
\text { nutrition education. Caregivers } \\
\text { identified three barriers to } \\
\text { providing healthy meals: (a) } \\
\text { scarcity of time, (b) external } \\
\text { challenges, and (c) health } \\
\text { problems of the child" }\end{array}$ & High \\
\hline $\begin{array}{l}\text { (Moore, } \\
\text { Tapper, \& } \\
\text { Murphy, 2010) }\end{array}$ & $\begin{array}{l}\text { Cardiff, } \\
\text { Wales. UK }\end{array}$ & $\begin{array}{l}12 \text { mothers of } \\
\text { children aged 3-5 } \\
\text { Med-high SES }\end{array}$ & $\begin{array}{l}\text { Semi-structured } \\
\text { interviews } \\
\text { "Data were analyzed }\end{array}$ & $\begin{array}{l}\text { "Mothers spontaneously } \\
\text { classified their child as a 'good' } \\
\text { or a 'bad' eater. Consumption } \\
\text { emerged as the dominant feeding }\end{array}$ & Moderate \\
\hline
\end{tabular}




\begin{tabular}{|c|c|c|c|c|c|}
\hline & & $\begin{array}{l}\text { All were white, } 11 \\
\text { being of British } \\
\text { origin and } 1 \text { from } \\
\text { Brazil. }\end{array}$ & $\begin{array}{l}\text { using thematic and } \\
\text { interpretative } \\
\text { techniques" }\end{array}$ & $\begin{array}{l}\text { goal. For 'bad' eaters, a short- } \\
\text { term goal of consuming any food, } \\
\text { rather than no food, was } \\
\text { adopted. For 'good' eaters, a } \\
\text { long-term goal of consuming a } \\
\text { varied, well-balanced diet was } \\
\text { favoured. Liking as a feeding goal } \\
\text { was not mentioned." }\end{array}$ & \\
\hline (Tipton, 2014) & $\begin{array}{l}\text { New Orleans } \\
\text { area, US }\end{array}$ & $\begin{array}{l}18 \text { female, } 1 \text { male. } \\
\text { Caregivers of a non- } \\
\text { Hispanic black child } \\
\text { between the ages of } \\
\text { 2-5 years. } \\
\text { Low SES. } \\
\text { Caregiver ethnicity } \\
\text { not stated }\end{array}$ & $\begin{array}{l}\text { Small group semi- } \\
\text { structured } \\
\text { interviews } \\
\text { consisting of } 2-3 \\
\text { caregivers } \\
\text { Elicitation } \\
\text { interviews with } \\
\text { analysis framework } \\
\text { based on Theory of } \\
\text { Planned Behaviour }\end{array}$ & $\begin{array}{l}\text { "Behavioral beliefs concerning } \\
\text { SSB intake among preschoolers } \\
\text { such as the disadvantage of } \\
\text { hyperactivity and the benefits of } \\
\text { convenience and keeping } \\
\text { children content. New insight on } \\
\text { normative and control factors } \\
\text { that emerged include conflict } \\
\text { with grandparents, the } \\
\text { perception that preschool staff } \\
\text { and other parents of young } \\
\text { children would approve of } \\
\text { serving SSBs to preschoolers, and } \\
\text { the belief that serving SSBs will } \\
\text { prevent children from acting out" }\end{array}$ & High \\
\hline $\begin{array}{l}\text { (Nielsen, } \\
\text { Michaelsen, \& } \\
\text { Holm, 2013) }\end{array}$ & $\begin{array}{l}\text { Copenhagen, } \\
\text { Denmark }\end{array}$ & $\begin{array}{l}45 \text { mothers of } \\
\text { children aged } 7 \text { or } \\
13 \text { months. } \\
\text { Medium SES ( } 27 \\
\text { high education, } 24\end{array}$ & $\begin{array}{l}\text { Template analysis, } \\
\text { inductive and }\end{array}$ & $\begin{array}{l}\text { "The themes are as follows: } \\
\text { serving healthy food; integration } \\
\text { of the child's food into the food of } \\
\text { the family and the wider social } \\
\text { environment; management of } \\
\text { family relations and everyday }\end{array}$ & Moderate \\
\hline
\end{tabular}


Additional file 3: Summary table of included studies

\begin{tabular}{|c|c|c|c|c|c|}
\hline & & $\begin{array}{l}\text { low education) } \\
\text { Ethnicity not stated }\end{array}$ & deductive & $\begin{array}{l}\text { life; and use of public nutritional } \\
\text { guidelines. }\end{array}$ & \\
\hline $\begin{array}{l}\text { (A Horodynski } \\
\text { \& Arndt, 2005) }\end{array}$ & $\begin{array}{l}\text { Jackson, } \\
\text { Mississippi, } \\
\text { US. }\end{array}$ & $\begin{array}{l}6 \text { fathers of } \\
\text { children aged 3-5 } \\
\text { Low SES } \\
\text { All African } \\
\text { American }\end{array}$ & $\begin{array}{l}\text { One focus group } \\
\text { Analysis methods } \\
\text { not stated but in the } \\
\text { results section } \\
\text { refers to 'content } \\
\text { analysis' }\end{array}$ & $\begin{array}{l}\text { "Five themes emerged regarding } \\
\text { nutrition and mealtime rituals } \\
\text { and routines of African- } \\
\text { American fathers of toddlers: (a) } \\
\text { mealtime rituals and routines, } \\
\text { (b) division of responsibility, (c) } \\
\text { family constellation, (d) } \\
\text { knowledge about healthy eating } \\
\text { behaviors, and (e) tension during } \\
\text { mealtime." }\end{array}$ & Low \\
\hline $\begin{array}{l}\text { (Freeman \& } \\
\text { Stevens, 2008) }\end{array}$ & $\begin{array}{l}\text { Belfast, } \\
\text { Northern } \\
\text { Ireland, UK }\end{array}$ & $\begin{array}{l}34 \text { mothers of } \\
\text { children aged } \\
\text { between } 3 \text { and } 4 \\
\text { years with nursing } \\
\text { caries. } \\
\text { Low SES } \\
\text { Ethnicity not stated } \\
\text { but predominantly } \\
\text { White area }\end{array}$ & $\begin{array}{l}\text { In depth interviews } \\
\text { Grounded theory }\end{array}$ & $\begin{array}{l}\text { "...what emerged was an } \\
\text { appreciation of the time } \\
\text { concerns, which the mothers } \\
\text { experienced when caring for } \\
\text { their children together with their } \\
\text { attempts at resolution. Time } \\
\text { concerns and fears of disturbed } \\
\text { mothering and poor parenting } \\
\text { provided important insights into } \\
\text { why the mothers persisted in } \\
\text { prolonged bottle feeding." }\end{array}$ & Moderate \\
\hline $\begin{array}{l}\text { (Kalinowski et } \\
\text { al., 2012) }\end{array}$ & $\begin{array}{l}\text { Midwestern } \\
\text { United States }\end{array}$ & $\begin{array}{l}91 \text { mothers of 3-5 } \\
\text { year old's } \\
\text { Low SES }\end{array}$ & $\begin{array}{l}\text { Semi-structured } \\
\text { interviews } \\
\text { Constant } \\
\text { comparative }\end{array}$ & $\begin{array}{l}\text { "Three themes: 1) negative } \\
\text { memories of being fed in } \\
\text { childhood } \\
\text { 2) Maternal emotional } \\
\text { investment in the child enjoying }\end{array}$ & High \\
\hline
\end{tabular}




\begin{tabular}{|c|c|c|c|c|c|}
\hline & & $\begin{array}{l}32 \text { were Hispanic, } \\
30 \text { African } \\
\text { American, and } 29 \\
\text { white; }\end{array}$ & method & $\begin{array}{l}\text { the meal 3) Attributing obesity in } \\
\text { other people's children to inept } \\
\text { or neglectful parenting }\end{array}$ & \\
\hline $\begin{array}{l}\text { (Hildebrand \& } \\
\text { Shriver, 2010) }\end{array}$ & $\begin{array}{l}\text { South- } \\
\text { central part } \\
\text { of US }\end{array}$ & $\begin{array}{l}\text { Qualitative sample } \\
\text { only: } \\
18 \text { Female and } 4 \\
\text { male caregivers of } \\
\text { children aged 2-5 } \\
\text { Low SES } \\
\text { African American }\end{array}$ & $\begin{array}{l}\text { Focus groups } \\
\text { Analyzed using } \\
\text { framework based on } \\
\text { Transtheoretical } \\
\text { Model of Behaviour } \\
\text { Change }\end{array}$ & $\begin{array}{l}\text { "In general, parents understood } \\
\text { the health benefits provided by } \\
\text { fruits and vegetables. Although } \\
\text { they believed fresh produce was } \\
\text { healthier, they frequently } \\
\text { purchased canned or frozen } \\
\text { because of the extended shelf- } \\
\text { life, convenience, and expense." }\end{array}$ & Moderate \\
\hline $\begin{array}{l}\text { (Carnell, } \\
\text { Cooke, Cheng, } \\
\text { Robbins, \& } \\
\text { Wardle, 2011) }\end{array}$ & UK & $\begin{array}{l}36 \text { mothers of } \\
\text { children aged 3-5 } \\
\text { Med-high SES } \\
\text { Mostly White } \\
\text { ethnicity }\end{array}$ & $\begin{array}{l}\text { Telephone } \\
\text { interviews (14) and } \\
\text { diaries (22) } \\
\text { Framework Analysis }\end{array}$ & $\begin{array}{l}\text { "Parents described a wide range } \\
\text { of efforts to promote or restrict } \\
\text { intake that were largely } \\
\text { motivated by practical and health } \\
\text { considerations and only rarely by } \\
\text { concern about weight. There was } \\
\text { also evidence for instrumental } \\
\text { feeding, rules surrounding meal- } \\
\text { time, child involvement, and } \\
\text { parental flexibility in relation to } \\
\text { feeding. Almost all parents } \\
\text { described responding to } \\
\text { children's appetitive traits..." }\end{array}$ & Moderate \\
\hline $\begin{array}{l}\text { (Lindsay, } \\
\text { Sussner, } \\
\text { Greaney, \& }\end{array}$ & Boston, US & $\begin{array}{l}51 \text { mothers of } \\
\text { children aged 2-5 }\end{array}$ & $\begin{array}{l}\text { Six focus groups and } \\
20 \text { in-depth } \\
\text { interviews }\end{array}$ & $\begin{array}{l}\text { "Respondents related } \\
\text { environmental influences to child } \\
\text { feeding, diet, and activity, }\end{array}$ & High \\
\hline
\end{tabular}


Additional file 3: Summary table of included studies

\begin{tabular}{|c|c|c|c|c|c|}
\hline $\begin{array}{l}\text { Peterson, } \\
2009 \text { ) }\end{array}$ & & $\begin{array}{l}\text { Low SES } \\
\text { Latina immigrants } \\
\text { (Central America } \\
\text { and Dominican } \\
\text { Republic) }\end{array}$ & $\begin{array}{l}\text { Content analysis } \\
\text { organized by } \\
\text { domains of the } \\
\text { socio-ecological } \\
\text { model }\end{array}$ & $\begin{array}{l}\text { namely, supermarket proximity, } \\
\text { food cost, access to recreational } \\
\text { facilities, neighborhood safety, } \\
\text { and weather." }\end{array}$ & \\
\hline $\begin{array}{l}\text { (Lindsay, } \\
\text { Sussner, } \\
\text { Greaney, \& } \\
\text { Peterson, } \\
\text { 2010) }\end{array}$ & As above & As above & $(\sqrt[3]{0)}=$ & $\begin{array}{l}\text { "Although subjects understood } \\
\text { the health and social } \\
\text { consequences related to } \\
\text { overweight, many discussed the } \\
\text { pressures of familial and cultural } \\
\text { influences endorsing a "chubby } \\
\text { child." }\end{array}$ & High \\
\hline $\begin{array}{l}\text { (Duncanson \& } \\
\text { Burrows, } \\
\text { 2013) }\end{array}$ & $\begin{array}{l}\text { Rural } \\
\text { Australia. } \\
\text { Northern } \\
\text { New South } \\
\text { Wales }\end{array}$ & $\begin{array}{l}21 \text { parents of } \\
\text { children aged 2-5 } \\
\text { ( } 3 \text { fathers, } 18 \\
\text { mothers) } \\
\text { Low SES } \\
\text { Ethnicity not stated } \\
\text { except "higher than } \\
\text { state average } \\
\text { Aboriginal" }\end{array}$ & $\begin{array}{l}\text { Semi-structured } \\
\text { interviews } \\
\text { Inductive and } \\
\text { deductive analysis. } \\
\text { A-priori codes based } \\
\text { on Theory of } \\
\text { Planned Behaviour }\end{array}$ & $\begin{array}{l}\text { "Behavioral intention to change } \\
\text { feeding practices was limited by } \\
\text { a belief that child's dietary intake } \\
\text { is above average compared with } \\
\text { their peer group. Perceived } \\
\text { control over child dietary intake } \\
\text { was influenced by food } \\
\text { advertising, extended family, and } \\
\text { peer influences." }\end{array}$ & High \\
\hline $\begin{array}{l}\text { (Peters, } \\
\text { Parletta, } \\
\text { Lynch, \& } \\
\text { Campbell, }\end{array}$ & $\begin{array}{l}\text { South } \\
\text { Australia }\end{array}$ & $\begin{array}{l}21 \text { parents (17 } \\
\text { mothers, } 3 \text { fathers) } \\
\text { of } 2-5 \text { year old } \\
\text { children }\end{array}$ & $\begin{array}{l}\text { Focus groups } \\
\text { Thematic analysis }\end{array}$ & $\begin{array}{l}\text { "Both groups of parents [healthy } \\
\text { v's unhealthy] believed it was } \\
\text { important to provide healthy } \\
\text { diets for their child; however }\end{array}$ & Moderate \\
\hline
\end{tabular}




\begin{tabular}{|c|c|c|c|c|c|}
\hline 2014) & & $\begin{array}{l}\text { Med-high SES } \\
\text { Ethnicity not stated }\end{array}$ & & $\begin{array}{l}\text { negative and controlling } \\
\text { practices reported by the } \\
\text { 'unhealthy' group appeared to be } \\
\text { less effective and associated with } \\
\text { conflict, stress, poorer diet and } \\
\text { increased weight and were } \\
\text { irrespective of SES }\end{array}$ & \\
\hline $\begin{array}{l}\text { (Pagnini, } \\
\text { Wilkenfeld, } \\
\text { King, Booth, \& } \\
\text { Booth, 2007) }\end{array}$ & $\begin{array}{l}\text { New South } \\
\text { Wales, } \\
\text { Australia }\end{array}$ & $\begin{array}{l}32 \text { mothers of } 2-5 \\
\text { year old children } \\
\text { Mixed SES } \\
\text { Ethnicity not stated }\end{array}$ & $\begin{array}{l}\text { Focus groups } \\
\text { Thematic analysis }\end{array}$ & $\begin{array}{l}\text { "Providing food was an } \\
\text { emotional issue for the mothers } \\
\text { in this study. They were more } \\
\text { concerned about their young } \\
\text { children being underweight than } \\
\text { overweight, and this increased } \\
\text { their stress around children's } \\
\text { eating. Food treats were } \\
\text { perceived as entitlements. } \\
\text { Mothers did believe that they } \\
\text { were responsible for their } \\
\text { children's eating, but } \\
\text { acknowledged the influence of } \\
\text { other environmental factors } \\
\text { related to food retail and } \\
\text { marketing." }\end{array}$ & Moderate \\
\hline $\begin{array}{l}\text { (Herman, } \\
\text { Malhotra, } \\
\text { Wright, Fisher, } \\
\text { \& Whitaker, } \\
\text { 2012) }\end{array}$ & $\begin{array}{l}\text { Philadelphia, } \\
\text { USA }\end{array}$ & $\begin{array}{l}32 \text { mothers of } \\
\text { children 3-5 years } \\
\text { Low SES } \\
29 \text { Black, } 3 \text { Other, }\end{array}$ & $\begin{array}{l}\text { Focus groups } \\
\text { Constant } \\
\text { comparative } \\
\text { analysis }\end{array}$ & $\begin{array}{l}\text { “Mothers' aspirations were to: } 1 \text { ) } \\
\text { prevent hyperactivity and tooth } \\
\text { decay by limiting children's sugar } \\
\text { intake, } 2 \text { ) use feeding to teach } \\
\text { their children life lessons about } \\
\text { limit setting and structure, and } 3 \text { ) }\end{array}$ & Moderate \\
\hline
\end{tabular}


Additional file 3: Summary table of included studies

\begin{tabular}{|c|c|c|c|c|c|}
\hline & & non-White & & $\begin{array}{l}\text { be responsive to children during } \\
\text { mealtimes to guide decisions } \\
\text { about portions. Especially } \\
\text { around setting limits with sweets } \\
\text { and snacks, mothers faced the } \\
\text { challenges of: 1) being nagged by } \\
\text { children's food requests, 2) being } \\
\text { undermined by other adults in } \\
\text { the family, and 3) having bad } \\
\text { memories from childhood that } \\
\text { made it hard to deny children's } \\
\text { food requests" }\end{array}$ & \\
\hline $\begin{array}{l}\text { (Horodynski, } \\
\text { Brophy-Herb, } \\
\text { Henry, Smith, } \\
\& \\
\text { Weatherspoon, } \\
\text { 2009) }\end{array}$ & $\begin{array}{l}2 \text { different } \\
\text { cities, } \\
\text { Midwestern } \\
\text { US }\end{array}$ & $\begin{array}{l}27 \text { mothers of } \\
\text { infants 1-3 years } \\
\text { Low SES } \\
\text { African American }\end{array}$ & $\begin{array}{l}\text { Focus groups } \\
\text { Content analysis }\end{array}$ & $\begin{array}{l}\text { "4 major themes: (1) maternal } \\
\text { perceptions of healthy toddlers, } \\
\text { (2) maternal food choices for } \\
\text { toddlers, (3) maternal } \\
\text { expectations about toddler } \\
\text { autonomy and self-regulation of } \\
\text { feeding, and (4) mealtime } \\
\text { context and interaction." }\end{array}$ & Moderate \\
\hline
\end{tabular}


Additional file 4: CERQual judgment table

\begin{tabular}{|c|c|c|c|c|c|c|}
\hline Review finding & $\begin{array}{l}\text { Studies } \\
\text { contributing } \\
\text { to review } \\
\text { finding }\end{array}$ & $\begin{array}{l}\text { Methodological } \\
\text { limitations }\end{array}$ & Relevance & Adequacy & Coherence & $\begin{array}{l}\text { Overall CERQual } \\
\text { confidence in the } \\
\text { finding and } \\
\text { explanation of } \\
\text { judgement }\end{array}$ \\
\hline $\begin{array}{l}\text { Caregivers may be more } \\
\text { likely to offer sweet } \\
\text { drinks and snacks in } \\
\text { situations where an } \\
\text { infant is upset, bored, is } \\
\text { seen as deserving a } \\
\text { reward or a 'treat'. }\end{array}$ & $\begin{array}{l}\text { (A } \\
\text { Horodynski \& } \\
\text { Arndt, 2005; } \\
\text { Carnell et al., } \\
\text { 2011; Hughes } \\
\text { et al., 2010; } \\
\text { Lindsay et al., } \\
\text { 2009, 2010; } \\
\text { Moore et al., } \\
\text { 2010; Omar } \\
\text { et al., 2010; } \\
\text { Tipton, 2014) }\end{array}$ & $\begin{array}{l}\text { Minor } \\
\text { methodological } \\
\text { limitations } \\
4 \text { studies high } \\
\text { quality, } 2 \\
\text { moderate and } 1 \\
\text { low quality. }\end{array}$ & $\begin{array}{l}\text { Moderate relevance } \\
\text { Caregivers: All } \\
\text { caregivers of children } \\
>2 \text { years, } 5 \text { studies } \\
\text { with mothers, } 2 \\
\text { studies included } \\
\text { mostly or all fathers. } \\
\text { SES: } 6 \text { studies with } \\
\text { low-income samples, } \\
2 \text { with med-high SES } \\
\text { samples. } \\
\text { Ethnicity: } 4 \text { samples } \\
\text { mostly White, } 1 \\
\text { African American, } 1 \\
\text { ethnicity not-stated, } \\
\text { and } 1 \text { Latina. }\end{array}$ & $\begin{array}{l}\text { Moderate } \\
\text { adequacy } \\
7 \text { Studies from } \\
\text { the UK and US, } \\
\text { with mostly } \\
\text { medium to large } \\
\text { sample sizes. } \\
\text { Moderately rich } \\
\text { data from the } \\
\text { seven studies } \\
\text { overall. }\end{array}$ & $\begin{array}{l}\text { High } \\
\text { coherence } \\
\text { Variation only } \\
\text { in the type of } \\
\text { behaviour } \\
\text { being } \\
\text { managed }\end{array}$ & $\begin{array}{l}\text { Moderate confidence } \\
\text { Minor concerns } \\
\text { regarding } \\
\text { methodological } \\
\text { limitations. High } \\
\text { coherence. Moderate } \\
\text { (indirect) relevance, } \\
\text { with no studies } \\
\text { including caregivers of } \\
\text { infants younger than } 2 \\
\text { years. Moderate } \\
\text { adequacy due to } \\
\text { sufficient quantity but } \\
\text { with limitations in the } \\
\text { richness of the data. }\end{array}$ \\
\hline
\end{tabular}




\begin{tabular}{|c|c|c|c|c|c|c|}
\hline $\begin{array}{l}\text { Caregivers may be more } \\
\text { likely to offer sweet } \\
\text { drinks and snacks to } \\
\text { infants during special } \\
\text { occasions and } \\
\text { celebrations, or if } \\
\text { sugary foods are seen as } \\
\text { part of the 'food culture' } \\
\text { of the family. }\end{array}$ & $\begin{array}{l}\text { (A } \\
\text { Horodynski \& } \\
\text { Arndt, 2005; } \\
\text { Carnell et al., } \\
\text { 2011; } \\
\text { Duncanson \& } \\
\text { Burrows, } \\
\text { 2013; } \\
\text { Herman et al., } \\
\text { 2012; } \\
\text { Horodynski et } \\
\text { al., 2009; } \\
\text { Kalinowski et } \\
\text { al., 2012; } \\
\text { Lindsay et al., } \\
\text { 2009; Nielsen } \\
\text { et al., 2013; } \\
\text { Peters et al., } \\
\text { 2014) }\end{array}$ & 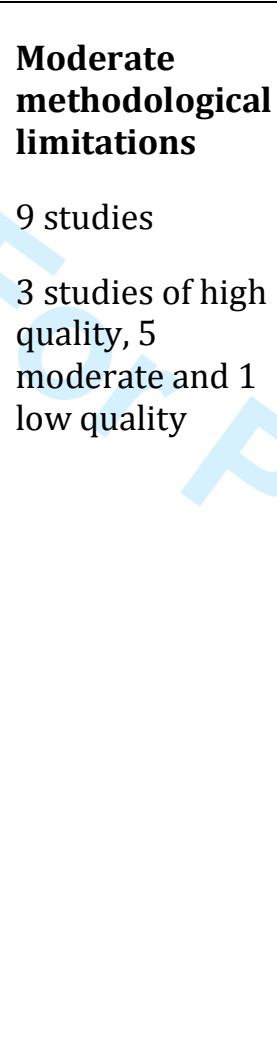 & $\begin{array}{l}\text { High relevance } \\
\text { Caregivers: } 4 \text { studies } \\
\text { with mostly mothers } \\
\text { (12 fathers in total) } \\
\text { of children over } 2 \\
\text { years, } 2 \text { with mothers } \\
\text { of children under } 2 \\
\text { years. } \\
\text { SES: } 6 \text { Low, 3Med- } \\
\text { high } \\
\text { Ethnicity: } 3 \text { African- } \\
\text { American, } 2 \text { not } \\
\text { stated, } 1 \text { mostly } \\
\text { White, } 1 \text { Aboriginal, } 1 \\
\text { Latina, } 1 \text { mixed } \\
\text { Hispanic, African } \\
\text { American and White }\end{array}$ & 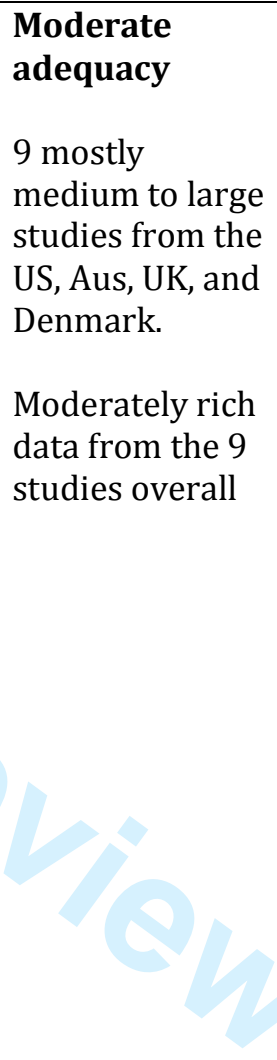 & $\begin{array}{l}\text { High } \\
\text { coherence } \\
\text { Consistent } \\
\text { view that } \\
\text { caregivers } \\
\text { frame child } \\
\text { feeding in the } \\
\text { context of the } \\
\text { family 'food } \\
\text { culture'. The } \\
\text { only } \\
\text { exception to } \\
\text { this was in } \\
\text { the very early } \\
\text { phase of } \\
\text { complementa } \\
\text { ry feeding (7 } \\
\text { months), } \\
\text { where at this } \\
\text { stage the } \\
\text { infants meals } \\
\text { were seen as } \\
\text { 'a separate } \\
\text { category' }\end{array}$ & $\begin{array}{l}\text { Moderate } \\
\text { methodological } \\
\text { limitations. High } \\
\text { coherence. High } \\
\text { relevance. Moderate } \\
\text { adequacy due to } \\
\text { sufficient quantity but } \\
\text { with limitations in the } \\
\text { richness of the data }\end{array}$ \\
\hline $\begin{array}{l}\text { Caregivers may be more } \\
\text { likely to offer sugary } \\
\text { drinks and snacks to } \\
\text { infants if they perceive } \\
\text { that the infant is unwell, } \\
\text { or has a history of being }\end{array}$ & $\begin{array}{l}\text { (Carnell et al., } \\
\text { 2011; } \\
\text { Duncanson \& } \\
\text { Burrows, } \\
\text { 2013; Lindsay } \\
\text { et al., 2010; }\end{array}$ & 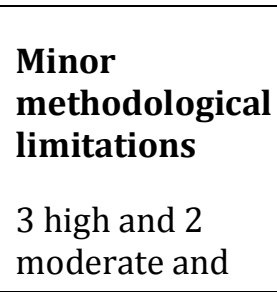 & $\begin{array}{l}\text { Moderate relevance } \\
\text { Caregivers: } 4 \text { studies } \\
\text { with mostly mothers } \\
\text { of children aged 2-5, } \\
1 \text { study mostly }\end{array}$ & $\begin{array}{l}\text { Moderate } \\
\text { Adequacy } \\
5 \text { studies with } \\
\text { medium to large } \\
\text { sample sizes }\end{array}$ & $\begin{array}{l}\text { High } \\
\text { coherence } \\
\text { All studies in } \\
\text { agreement } \\
\text { that }\end{array}$ & $\begin{array}{l}\text { Moderate confidence } \\
\text { Minor methodological } \\
\text { limitations. High } \\
\text { coherence. Moderate } \\
\text { (indirect) relevance, }\end{array}$ \\
\hline
\end{tabular}


Additional file 4: CERQual judgment table

\begin{tabular}{|c|c|c|c|c|c|c|}
\hline $\begin{array}{l}\text { underweight or low } \\
\text { birth weight. }\end{array}$ & $\begin{array}{l}\text { Omar et al., } \\
\text { 2010; Pagnini } \\
\text { et al., 2007) }\end{array}$ & quality & $\begin{array}{l}\text { fathers } \\
\text { SES: } 1 \text { mixed, } 1 \text { med- } \\
\text { high, } 3 \text { low } \\
\text { Ethnicity: } 1 \text { ethnicity } \\
\text { not stated, } 2 \text { mostly } \\
\text { White, } 1 \text { Aboriginal, } 1 \\
\text { Latina }\end{array}$ & $\begin{array}{l}\text { from the UK, Aus } \\
\text { and US } \\
\text { Moderately rich } \\
\text { data provided by } \\
\text { the } 5 \text { studies }\end{array}$ & $\begin{array}{l}\text { caregivers are } \\
\text { influenced by } \\
\text { their } \\
\text { perception of } \\
\text { the specific } \\
\text { health risks of } \\
\text { their child }\end{array}$ & $\begin{array}{l}\text { with no studies } \\
\text { including caregivers of } \\
\text { infants under } 2 \text { years } \\
\text { and under- } \\
\text { representation of } \\
\text { fathers. Moderate } \\
\text { adequacy due to a } \\
\text { sufficient quantity but } \\
\text { limitations in the } \\
\text { richness of data. }\end{array}$ \\
\hline
\end{tabular}


Additional file 4: CERQual judgment table

\begin{tabular}{|c|c|c|c|c|c|c|}
\hline & $\begin{array}{l}\text { et al., 2014; } \\
\text { Tipton, 2014) }\end{array}$ & & & & & \\
\hline $\begin{array}{l}\text { Caregivers may be more } \\
\text { likely to offer infants } \\
\text { sugary drinks and } \\
\text { snacks when they are } \\
\text { busy, tired, rushed, or } \\
\text { struggling to cope with } \\
\text { negative emotions. This } \\
\text { may become more } \\
\text { important if caregivers } \\
\text { are coping with } \\
\text { negative emotions and } \\
\text { difficult life } \\
\text { circumstances in } \\
\text { general. }\end{array}$ & $\begin{array}{l}\text { (A } \\
\text { Horodynski \& } \\
\text { Arndt, 2005; } \\
\text { Carnell et al., } \\
\text { 2011; } \\
\text { Duncanson \& } \\
\text { Burrows, } \\
2013 ; \\
\text { Freeman \& } \\
\text { Stevens, } \\
\text { 2008; } \\
\text { Herman et al., } \\
2012 ; \\
\text { Hildebrand \& } \\
\text { Shriver, 2010; } \\
\text { Hughes et al., } \\
\text { 2010; } \\
\text { Kalinowski et } \\
\text { al., 2012; } \\
\text { Lindsay et al., } \\
\text { 2009; Moore } \\
\text { et al., 2010; } \\
\text { Nielsen et al., } \\
\text { 2013; Omar } \\
\text { et al., 2010; }\end{array}$ & $\begin{array}{l}\text { Minor } \\
\text { methodological } \\
\text { limitations }\end{array}$ & $\begin{array}{l}\text { High Relevance } \\
\text { Caregivers: } 10 \text { with } \\
\text { mothers of children } \\
\text { aged }>2,2 \text { with } \\
\text { mothers of infants } \\
<2,1 \text { study with } \\
\text { mostly fathers } \\
\text { SES: } 3 \text { med-high, } 10 \\
\text { low } \\
\text { Ethnicity: } 5 \text { mostly } \\
\text { White, } 3 \text { not stated, } 2 \\
\text { mostly African- } \\
\text { American, } 1 \text { Latina, } 1 \\
\text { Aboriginal, } 1 \text { mixed } \\
\text { Hispanic, African } \\
\text { American and White }\end{array}$ & $\begin{array}{l}\text { High Adequacy } \\
13 \text { medium to } \\
\text { large studies } \\
\text { studies from the } \\
\text { UK, US, AUS, and } \\
\text { Denmark. } \\
\text { Rich data } \\
\text { provided by the } \\
13 \text { studies } \\
\text { overall }\end{array}$ & $\begin{array}{l}\text { High } \\
\text { Coherence } \\
\text { High } \\
\text { coherence } \\
\text { between and } \\
\text { within studies }\end{array}$ & $\begin{array}{l}\text { High Confidence } \\
\text { Minor concerns } \\
\text { regarding } \\
\text { methodological } \\
\text { limitations. High } \\
\text { coherence. High } \\
\text { relevance, albeit with } \\
\text { under representation } \\
\text { of fathers. High } \\
\text { adequacy due to a } \\
\text { sufficient quantity and } \\
\text { rich data }\end{array}$ \\
\hline
\end{tabular}


Additional file 4: CERQual judgment table

\begin{tabular}{|c|c|c|c|c|c|c|}
\hline & $\begin{array}{l}\text { Peters et al., } \\
\text { 2014; Tipton, } \\
\text { 2014) }\end{array}$ & & & & & \\
\hline $\begin{array}{l}\text { Caregivers may be more } \\
\text { likely to offer sugary } \\
\text { drinks and snacks to } \\
\text { infants, when } \\
\text { encouraged to do so by } \\
\text { other family members, } \\
\text { or if other children are } \\
\text { consuming them. This } \\
\text { may be of greater } \\
\text { relevance where the } \\
\text { culture of the family } \\
\text { views food as an } \\
\text { expression of love, or } \\
\text { where there is a recent } \\
\text { cultural memory of food } \\
\text { insecurity. }\end{array}$ & $\begin{array}{l}\text { (Carnell et al., } \\
\text { 2011; } \\
\text { Duncanson \& } \\
\text { Burrows, } \\
\text { 2013; } \\
\text { Herman et al., } \\
\text { 2012; } \\
\text { Horodynski et } \\
\text { al., 2009; } \\
\text { Hughes et al., } \\
\text { 2010; } \\
\text { Kalinowski et } \\
\text { al., 2012; } \\
\text { Lindsay et al., } \\
\text { 2009, 2010; } \\
\text { Moore et al., } \\
\text { 2010; Omar } \\
\text { et al., 2010; } \\
\text { Pagnini et al., } \\
\text { 2007; Peters } \\
\text { et al., 2014; } \\
\text { Tipton, 2014) }\end{array}$ & $\begin{array}{l}\text { Minor } \\
\text { methodological } \\
\text { limitations } \\
6 \text { high quality, } 6 \\
\text { moderate quality }\end{array}$ & $\begin{array}{l}\text { Moderate } \\
\text { Relevance } \\
\text { Caregivers: } 10 \\
\text { studies with mostly } \\
\text { mothers of children > } \\
2 \text { years, } 1 \text { with } \\
\text { mothers of infants < } \\
2 \text { years, } 1 \text { study with } \\
\text { mostly fathers } \\
\text { SES: } 3 \text { med-high, } 8 \\
\text { low, } 1 \text { mixed SES } \\
\text { Ethnicity: } 4 \text { mostly } \\
\text { White, } 1 \text { Aboriginal, } 2 \\
\text { African-American, } 1 \\
\text { Latina, } 4 \text { ethnicity not } \\
\text { stated, } 1 \text { mixed } \\
\text { Hispanic, African- } \\
\text { American and White }\end{array}$ & $\begin{array}{l}\text { High Adequacy } \\
12 \text { medium to } \\
\text { large studies } \\
\text { from the UK, US } \\
\text { and Aus. } \\
\text { Rich data } \\
\text { provided by the } \\
12 \text { studies }\end{array}$ & $\begin{array}{l}\text { High } \\
\text { coherence } \\
\text { High } \\
\text { coherence } \\
\text { across studies } \\
\text { that } \\
\text { caregivers are } \\
\text { influenced in } \\
\text { food choices } \\
\text { for their } \\
\text { infants by } \\
\text { other family } \\
\text { members and } \\
\text { peers }\end{array}$ & $\begin{array}{l}\text { High confidence } \\
\text { Minor concerns } \\
\text { regarding } \\
\text { methodological } \\
\text { limitations. High } \\
\text { coherence. Moderate } \\
\text { relevance, with under } \\
\text { representation of } \\
\text { fathers and caregivers } \\
\text { of infants younger than } \\
2 \text { years. High adequacy } \\
\text { due to a sufficient } \\
\text { quantity and rich data }\end{array}$ \\
\hline $\begin{array}{l}\text { Caregivers who have } \\
\text { memories of sugary } \\
\text { drinks and snacks being } \\
\text { restricted when they }\end{array}$ & $\begin{array}{l}\text { (Herman et } \\
\text { al., 2012; } \\
\text { Kalinowski et }\end{array}$ & $\begin{array}{l}\text { Moderate } \\
\text { methodological } \\
\text { limitations }\end{array}$ & $\begin{array}{l}\text { Moderate } \\
\text { Relevance } \\
\text { Caregivers: } 3 \text { studies }\end{array}$ & $\begin{array}{l}\text { Low Adequacy } \\
2 \text { medium and } 1 \\
\text { very large }\end{array}$ & $\begin{array}{l}\text { High } \\
\text { Coherence } \\
\text { Coherent }\end{array}$ & $\begin{array}{l}\text { Low confidence } \\
\text { Moderate concerns } \\
\text { regarding }\end{array}$ \\
\hline
\end{tabular}




\section{Additional file 4: CERQual judgment table}

\begin{tabular}{|c|c|c|c|c|c|c|}
\hline $\begin{array}{l}\text { were children may be } \\
\text { more likely to offer } \\
\text { sugary drinks and } \\
\text { snacks to their infants }\end{array}$ & $\begin{array}{l}\text { al., 2012; } \\
\text { Moore et al., } \\
\text { 2010) }\end{array}$ & $\begin{array}{l}2 \text { moderate and } 1 \\
\text { high quality }\end{array}$ & $\begin{array}{l}\text { with mothers of } \\
\text { children aged 3-5 } \\
\text { SES: } 1 \text { med-high, } 2 \\
\text { low } \\
\text { Ethnicity: } 1 \text { White, } 1 \\
\text { Black, } 1 \text { mixed } \\
\text { Hispanic, African- } \\
\text { American and White }\end{array}$ & $\begin{array}{l}\text { samples form } \\
\text { the UK and US } \\
\text { Moderately rich } \\
\text { data overall }\end{array}$ & $\begin{array}{l}\text { across the } 3 \\
\text { studies that } \\
\text { caregivers } \\
\text { wish to } \\
\text { improve upon } \\
\text { their own } \\
\text { child feeding } \\
\text { experiences }\end{array}$ & $\begin{array}{l}\text { methodological } \\
\text { limitations, moderate } \\
\text { (indirect and partial) } \\
\text { relevance, with no } \\
\text { caregivers of infants } \\
\text { younger than two, or } \\
\text { any fathers included. } \\
\text { Low adequacy due to } \\
\text { only a small number of } \\
\text { studies with some } \\
\text { limitations in the } \\
\text { richness of the data }\end{array}$ \\
\hline $\begin{array}{l}\text { Food environments: } \\
\text { Caregivers may be more } \\
\text { likely to offer infants } \\
\text { sugary drinks and } \\
\text { snacks in situations } \\
\text { where they don't have } \\
\text { access to convenient } \\
\text { alternatives, such as } \\
\text { fruit or water, at a } \\
\text { reasonable or no extra } \\
\text { cost }\end{array}$ & $\begin{array}{l}\text { (Carnell et al., } \\
2011 ; \\
\text { Hildebrand \& } \\
\text { Shriver, 2010; } \\
\text { Horodynski et } \\
\text { al., 2009; } \\
\text { Lindsay et al., } \\
\text { 2009; Omar } \\
\text { et al., 2010; } \\
\text { Pagnini et al., } \\
\text { 2007; Peters } \\
\text { et al., 2012; } \\
\text { Tipton, 2014) }\end{array}$ & $\begin{array}{l}\text { Moderate } \\
\text { methodological } \\
\text { limitations } \\
3 \text { high and } 5 \\
\text { moderate quality }\end{array}$ & $\begin{array}{l}\text { Moderate } \\
\text { Relevance } \\
\text { Caregivers: } 6 \text { with } \\
\text { mothers of children } \\
\text { aged 2-5, } 1 \text { with } \\
\text { mothers } 1 \text {-3 years, } 1 \\
\text { mostly fathers } \\
\text { SES: } 2 \text { med-high, } 5 \\
\text { low, } 1 \text { mixed } \\
\text { Ethnicity: } 2 \text { mostly } \\
\text { White, } 2 \text { African- } \\
\text { American, } 2 \text { not } \\
\text { stated, } 1 \text { Aboriginal, } 1 \\
\text { Latina }\end{array}$ & $\begin{array}{l}\text { Moderate } \\
\text { Adequacy } \\
8 \text { medium to } \\
\text { large studies } \\
\text { from the US, UK } \\
\text { and Aus. } \\
\text { A mixture of } \\
\text { moderately rich } \\
\text { and fairly thin } \\
\text { data }\end{array}$ & $\begin{array}{l}\text { High } \\
\text { Coherence } \\
\text { Agreement } \\
\text { between and } \\
\text { within studies }\end{array}$ & $\begin{array}{l}\text { Moderate concerns } \\
\text { regarding } \\
\text { methodological } \\
\text { limitations. High } \\
\text { coherence. Moderate } \\
\text { relevance due to } \\
\text { under-representation } \\
\text { of caregivers of infants } \\
\text { under } 2 \text { years and } \\
\text { fathers. Moderate } \\
\text { adequacy due to } \\
\text { sufficient quantity but } \\
\text { some limitations in the } \\
\text { richness of the data }\end{array}$ \\
\hline
\end{tabular}


Additional file 4: CERQual judgment table

http://mc.manuscriptcentral.com/qhr 